\title{
Anti-cancer potential of flavonoids: recent trends and future perspectives
}

\author{
Priya Batra $\cdot$ Anil K. Sharma
}

Received: 14 December 2012/ Accepted: 15 January 2013/Published online: 12 February 2013

(C) The Author(s) 2013. This article is published with open access at Springerlink.com

\begin{abstract}
Cancer is a major public health concern in both developed and developing countries. Several plant-derived anti-cancer agents including taxol, vinblastine, vincristine, the campothecin derivatives, topotecan, irinotecan and etoposide are in clinical use all over the world. Other promising anti-cancer agents include flavopiridol, roscovitine, combretastatin A-4, betulinic acid and silvestrol. From this list one can well imagine the predominance of polyphenols, flavonoids and their synthetic analogs in the treatment of ovarian, breast, cervical, pancreatic and prostate cancer. Flavonoids present in human diet comprise many polyphenolic secondary metabolites with broadspectrum pharmacological activities including their potential role as anti-cancer agents. A positive correlation between flavonoids-rich diet (from vegetables and fruits) and lower risk of colon, prostate and breast cancers lead to a question that whether flavonoids mediate the protective effects as chemopreventive agents or can interact with different genes and proteins to play role in chemotherapy. The current review emphasizes onto the therapeutic potential of flavonoids and their synthetic analogs as anticancer agents by providing new insights into the factors, regulation and molecular mechanisms along with their significant protein interactions.
\end{abstract}

Keywords Flavonoids - Anti-cancer - Breast cancer . Therapeutic potential $\cdot$ Health benefits $\cdot$ Dietary flavonoids

P. Batra · A. K. Sharma $(\square)$

Department of Biotechnology, MMEC,

Maharishi Markandeshwar University, Mullana,

Ambala, Haryana 133207, India

e-mail: anibiotech18@gmail.com

\section{Introduction}

Cancer chemoprevention, by the use of natural, dietary or synthetic agents that can reverse, suppress or prevent carcinogenic progression, has become an appealing strategy to combat the dogma associated with increasing cases of cancers worldwide (Tsao and Edward 2004). Epidemiological studies point to the fact that long-term consumption of diet rich in foods and vegetables reduces the risk of chronic diseases especially cancer (Wallstrom et al. 2000; Parr and Bolwell 2000; Arts and Hollman 2005; Patel 2008; Xiao et al. 2011). Such diets can minimize-exposure to deleterious substances, activation of procarcinogens and can maximize the intake of certain beneficial nutrients like isothiocyanates, unsaturated fatty acids, polyphenolic terpenoids (PPT), selenium, terpenes, etc. (Franco et al. 2004; Johnson 2004).

\section{Historical perspective}

In 1930, a new substance was isolated from oranges that can reduce the capillary permeability and is believed to be a member of a new class of vitamins hence designated as vitamin P, however, later on this substance was identified as a flavonoid (rutin). Flavonoids drew greater attention with the decreased incidence of cardiovascular diseases, in spite of a greater saturated fat intake in Mediterranean population, which was associated with red wine consumption (Renaud and de Lorgeril 1992). Flavonoids belong to a very vast group of plant secondary metabolites with variable phenolic structures and are found in fruits, vegetables, grains, bark, roots, stems, flowers, tea and wine (Nijeveldt et al. 2001). In plants, flavonoids are performing a variety of functions including pollination, seed dispersal, pollen tube growth, resorption of mineral nutrients, tolerance to abiotic stresses, protection against ultraviolet and allelopathic interactions, etc. (Gould 
and Lister 2005; Samanta et al. 2011; Hassan and Mathesius 2012). More than 8,000 different compounds of polyphenols have been known and that can be further subdivided into ten different general classes (Ververidis et al. 2007; Harborne and Williams 2000; Chahar et al. 2011). Flavonoids are part of this family and have more than 4,000 varieties (Harborne 1994). Isoflavonoids (phytoestrogens or non-steroidal estrogens) such as the soy isoflavones-genistein and daidzein, have also been known for their therapeutic significance particularly in the protection of human health (Wiseman et al. 2000; Stevens and Page 2004; Ørgaard and Jensen 2008; Xiao 2008; Ogbuewu et al. 2010; Wiseman et al. 2002). There are a variety of factors such as species, variety, climate, degree of ripeness and post harvest storage which influence the concentration of flavonoids in foods (Holland et al. 1995; Robards and Antolovich 1997; Pascual-Teresa et al. 2000; Modak et al. 2011). Flavonoids have a remarkable reducing ability and ability to interact with proteins (Haslam 1996; Havsteen 2002; Liu et al. 2010; McRae and Kennedy 2011). This review focus on biochemical studies carried out to analyze the possible health effects of flavonoids and to assess their potential in the prevention of degenerative diseases or their therapeutic value as potential drugs.

\section{Structural insight and classification}

Polyphenolic terpenoids are the most extensively studied flavonoids which have a characteristic C6-C3-C6 structure. The chemical structure of flavonoids is based on a $\mathrm{C}_{15}$ skeleton with a CHROMANE ring bearing a second aromatic ring $\mathrm{B}$ in position 2, 3 or 4 .

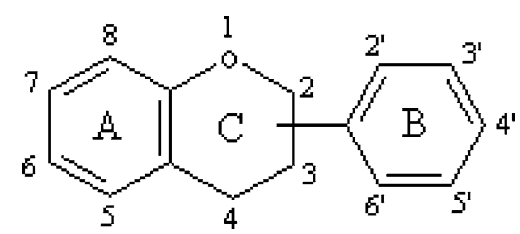

In a few cases, the six-membered heterocyclic ring $\mathrm{C}$ occurs in an isomeric open form or is replaced by a fivemembered ring.

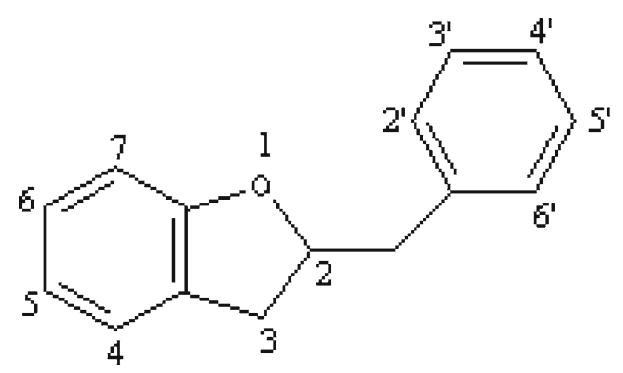

AURONES (2-benzyl-coumarone)
They have been further subdivided into flavones, flavonols, flavanones, flavanols, anthocyanins and isoflavones based on the nature of $\mathrm{C} 3$ element (Fig. 1). Different groups of flavonoids and their dietary sources are mentioned in Table 1. Flavonoids, especially flavanols, flavonols and anthocyanins are relatively abundant in human diet and possibly involved in prevention of cancers, cardiovascular diseases and neurodegeneration (Bazzano et al. 2002; Clifford 2004; Atmani et al. 2009; Fang et al. 2010; Xiao et al. 2011).

\section{Synthesis}

The flavonoids are formed in plants and participate in the light-dependent phase of photosynthesis during which they catalyze electron transport (Das 1994). They are synthesized from the aromatic amino acids-phenylalanine and tyrosine, together with acetate units (Heller and Forkmann 1993). Phenylalanine and tyrosine are converted to cinnamic acid and parahydroxycinnamic acid, respectively, by the action of phenylalanine and tyrosine ammonia lyases (Wagner and Farkas 1975). Cinnamic acid (or parahydroxycinnamic acid) condenses with acetate units to form the cinnamoyl structure of the flavonoids (Fries rearrangement). A variety of phenolic acids, such as caffeic acid, ferulic acid, and chlorogenic acid, are cinnamic acid derivatives. There is then alkali-catalyzed condensation of an ortho-hydroxyacetophenone with a benzaldehyde derivative generating chalcones and flavonones (Fig. 2), as well as a similar condensation of an ortho-hydroxyacetophenone with a benzoic acid derivative (acid chloride or anhydride), leading to 2-hydroxyflavanones and flavones (Heller and Forkmann 1993). The synthesis of chalcones and anthocyanidins has been described in detail by Dhar (1994). Biotransformation of flavonoids in the gut can release these cinnamic acid (phenolic acids) derivatives (Scheline 1991). In terms of their biosynthesis, the phenyl propanoid pathway produces a range of secondary metabolites such as phenolic acids, lignins, lignans and stilbenes using phenyl alanine and tyrosine as the precursor. After tannins, flavonoid glycosides are by far the most common dietary sources of flavonoids. Usually $110-121 \mathrm{mg} /$ day of flavonoids has been recommended as a healthy diet for an adult (Hertog et al. 1992, 1993a, 1993b).

\section{Metabolism}

The fate of orally and parenterally administered flavonoids in mammals was reviewed by Griffiths and Barrow (1972) and later by Hollman and Katan (1998). Considerable information is available regarding the metabolism of flavonoids in animals and to a very limited extent in 
Fig. 1 Subclasses of flavonoids<smiles>Cc1cc(-c2cc(=O)c3c(O)cc(O)cc3o2)cc(C)c1O</smiles>

Flavones

Flavonols<smiles>Cc1cc(C2CC(=O)c3c(O)cc(O)cc3O2)cc(C)c1O</smiles><smiles>Cc1cc([C@H]2Oc3cc(O)cc(O)c3CC2O)cc(C)c1O</smiles>

Flavanones

Catechins<smiles>Cc1cc(-c2coc3cc(O)cc(O)c3c2=O)cc(C)c1O</smiles>

Anthocyanidins

Isoflavones

humans (Hackett 1986; Scheline 1991). Hertog et al. (1992) measured the content of potentially anti-carcinogenic flavonoids of 28 vegetables, wine, and fruits frequently consumed in The Netherlands and the measured flavonoids were quercetin, kaempferol, myricetin, apigenin, and luteolin. The mean daily intake of these five antioxidant flavonoids was $23 \mathrm{mg} / \mathrm{day}$, which exceeds the intake of other familiar anti-oxidants such as b-carotene (2-3 mg/day) and vitamin $\mathrm{E}(7-10 \mathrm{mg} /$ day) and is about one-third the average intake of vitamin C (70-100 mg/day) (Hertog et al. 1993b). Quercetin is the most important contributor to the estimated intake of flavonoids, mainly from the consumption of apples and onions (Knekt et al. 1996; Gibellini et al. 2011; Giuliani et al. 2008). It is extremely difficult to estimate the daily human intake of flavonoids, especially because of the lack of standardized analytical methods (Scalbert and Williamson 2000). However, the average daily intake of the most abundant flavonoids, catechins, is $\sim 100 \mathrm{mg}$ (Perez-Vizcaino et al. 2009). Similar to daily intake, it is also quite complex to assess and quantify the bioavailability of flavonoids (Russo
2007). In countries such as Japan, Korea, China, and Taiwan, the mean daily intake of soy products has been estimated to be in the range of $10-50 \mathrm{~g}$ compared to only 1-3 $\mathrm{g}$ in the United States (Messina et al. 1994).

Flavonoid pharmacokinetics is complex, since they are usually contained as glucosides in fruits and vegetables, cleaved and glucuronated during uptake. Glucuronides may be metabolized, or stored or set free as aglycones by tissuespecific glucuronidases; thus, plasma concentration may not always be a good measure of bioavailability (Seelinger et al. 2008). Most flavonoids, except catechins, exist in nature as glycosides. Moreover, at least quercetin glucosides were absorbed better than the aglycone quercetin-bglucoside (Hollman and Katan 1998). Finally, supplementation of the diet should more appropriately use flavonoid glycosides instead of aglycones. However, this has been questioned by other researchers (Manach et al. 1997). The role of flavonoid glycosylation in facilitating absorption is questioned by the fact that catechin, which is not glycosylated in nature, is absorbed relatively efficiently (Okushio et al. 1996). Because the half-lives of conjugated 
Table 1 Different groups of flavonoids and their dietary sources

\begin{tabular}{|c|c|c|c|}
\hline $\begin{array}{l}\text { Flavonoid } \\
\text { group }\end{array}$ & Subgroup & Major sources & Anti-cancer properties \\
\hline Flavanols & $\begin{array}{l}\text { Flavan-3-ols: catechin, gallocatechin, } \\
\text { catechin-3-gallate, epicaechin, } \\
\text { epigallocatechin } \\
\text { Flavan-4-ols } \\
\text { Flavan-3,4-diols }\end{array}$ & $\begin{array}{l}\text { Chocolate, green and black tea, } \\
\text { beans, cherry, strawberries, cocoa, } \\
\text { apple }\end{array}$ & Human oral, rectal and prostate cancer \\
\hline Flavones & $\begin{array}{l}\text { Apigenin, chrysin, luteolin } \\
\text { Flavonol: kaempherol, myricetin, } \\
\text { quercetin, rutin } \\
\text { Flavanones: eriodictyol, hesperitin, } \\
\text { naringenin } \\
\text { Flavanonols: taxifolin }\end{array}$ & $\begin{array}{l}\text { Parsley, celery, capsicum, pepper, } \\
\text { broccoli } \\
\text { Brussel sprouts, apples, onion, curly } \\
\text { kale, leek, beans, cherries } \\
\text { Orange juice, grape fruit juice, } \\
\text { lemon juice } \\
\text { Milk thistle, red onion, acai palm, } \\
\text { Siberian larch tree }\end{array}$ & $\begin{array}{l}\text { Lung cancer, leukemia, stomach, colon, } \\
\text { thyroid, oral and laryngeal cancer, breast } \\
\text { cancer }\end{array}$ \\
\hline Anthocyanidins & $\begin{array}{l}\text { Cyanidin, delphinidin, malvidin, } \\
\text { petunidin, peonidin, pelargonidin }\end{array}$ & $\begin{array}{l}\text { Aubergine, black berries, black } \\
\text { currant, blue berries }\end{array}$ & Colorectal cancer \\
\hline Isoflavonoids & $\begin{array}{l}\text { Isoflavones: daidzein, genistein, glycitein } \\
\text { Isoflavane: equol }\end{array}$ & $\begin{array}{l}\text { Soy flour, soy beans, soy milk, miso, } \\
\text { tempeh, beer } \\
\text { Metabolized from daidzein by } \\
\text { intestinal bacteria }\end{array}$ & $\begin{array}{l}\text { Breast cancer, prostate cancer, colon, kidney } \\
\text { and thyroid cancer }\end{array}$ \\
\hline
\end{tabular}

flavonoids are rather long (23-28 h) (Young et al. 1999), accumulation may occur with regular intakes, which may in turn result in sufficiently active flavonoid concentrations (Nijeveldt et al. 2001). Flavanoid bioavailability and the mechanism by which flavonoids are absorbed from intestine and metabolized via microbial catabolism, conjugation in liver and enterocytes have been studied by a number of workers (Hollman and Katan 1999; Scalbert and Williamson 2000, Hollman 2004; Passamonti et al. 2009).

Studies in human and animals have indicated that some PPT (for example cinnamate conjugates, flavanols, quercetin glucosides) can be absorbed in the small intestine (Olthof et al. 2000, 2003; Nardini et al. 2002; Cermak et al. 2004) while quercetin, quercetin galactoside, rutin, naringenin-7-glucoside and many others are not. Mechanism of absorption has not been completely elucidated while the membrane transport of flavonoids is a fundamental part of their bioavailability in both plant and animal organisms, and current knowledge suggests the involvement of both ATP-dependent pumps and ATP-independent transporters (Passamonti et al. 2009).

Depending on PPT subclass, only 5-10\% of amount consumed is absorbed in small intestine and major part of that absorbed in the duodenum enters the circulation as methylated, sulfate-conjugated, glucuronide-conjugated and glycine-conjugated forms (Kroon et al. 2004). The rest 90-95\% of total PPT ingested plus any mammalian glucuronide excreted through bile pass to the colon where they are metabolized by gut microflora. Transformations may be extensive, and include the removal of sugars, removal of phenolic hydroxyls, fission of aromatic rings, hydrogenation, and metabolism to carbon dioxide, possibly via oxaloacetate (Walle et al. 2001). A substantial range of microbial metabolites has been identified, including phenols and aromatic acids, phenolic acids, or lactones possessing 0,1 , or 2 phenolic hydroxyls and up to five carbons in the side chain (Clifford and Brown 2006). The elimination half-lives are very variable, ranging from as low as $1 \mathrm{~h}$ (Meng et al. 2001) to values in excess of $20 \mathrm{~h}$ (Olthof et al. 2003).

\section{Flavonoid as anti-cancer agents}

Epidemiological studies

A huge number of epidemiological studies have been conducted to prove the protective effect of flavonoids against cancer. Increased consumption of lignans and greater plasma concentrations of their metabolites have been linked with reduced incidence of estrogen-related cancers in some (Pietinen et al. 2001; Dai et al. 2002; Boccardo et al. 2004; McCann et al. 2004) but not all studies, (Kilkkinen et al. 2004; Zeleniuch-Jacquotte et al. 2004) and a prospective study was equivocal (den Tonkelaar et al. 2001). It has been suggested that this inconsistency might have a genetic basis (McCann et al. 2002). Increased consumption of isoflavones has also been associated with decreased risk of estrogen-related cancers and vascular diseases (Arai et al. 2000; Birt et al. 2001). Data 
Fig. 2 Pathway of biosynthesis of flavonoids

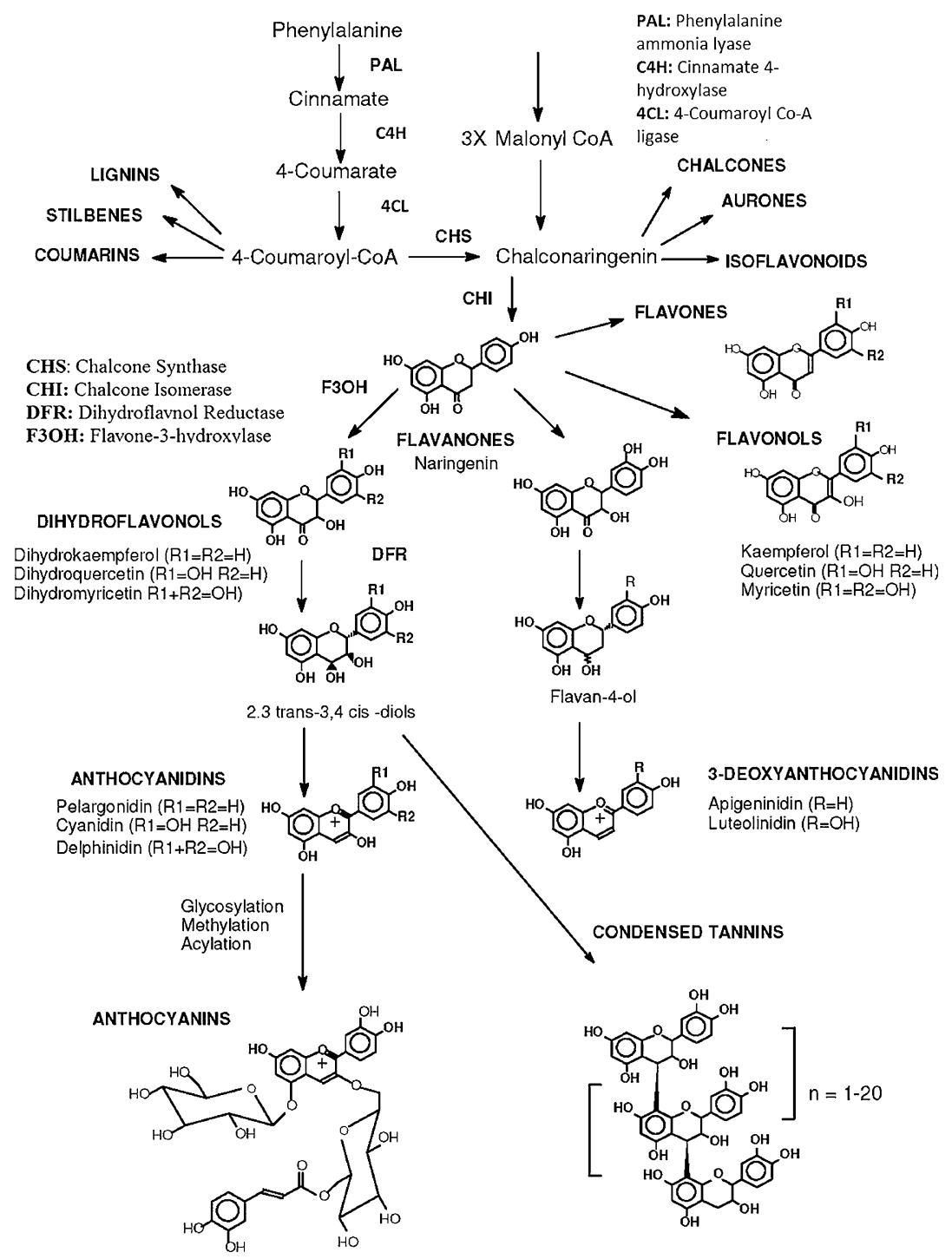

from four cohort studies and six case-control studies, which have examined associations of flavonoid intake with cancer risk revealed that flavonoids, especially quercetin, may reduce the risk of lung cancer in two studies but a nonsignificant increased risk in a third study. High versus low quercetin and kaempferol intakes were associated with 40 and $50 \%$ reduction in risk, respectively, for stomach cancer. There was no statistically significant association of any flavonoids with either bladder cancer or breast cancer risk (Neuhouser 2004). In a network of multicentric Italian case-control studies including about 10,000 incident, histologically confirmed cases of selected cancers and over 16,000 controls, the association of flavonoids, proanthocyanidins and cancer risk was evaluated by Rossi et al. (2010). It was found that total flavonoids, flavanones, and flavonols were inversely related to oral and laryngeal cancers (ORs, respectively, 0.56 and 0.60 for total flavonoids; 0.51 and 0.60 for flavanones; and 0.62 and 0.32 for flavonols). Flavonols were also inversely related to laryngeal cancer (OR 0.64), whereas flavanones were inversely related to esophageal cancer (OR 0.38). A reduced risk of colorectal cancer was found for high intake of anthocyanidins (OR 0.67), flavonols (OR 0.64), flavones (OR 0.78), and isoflavones (OR 0.76). Inverse relations with breast cancer were found for flavones (OR 0.81) and flavonols (OR 0.80). Flavonols (OR 0.63) and isoflavones (OR 0.51) were inversely associated to ovarian cancer, whereas flavonols (OR 0.69) and flavones (OR 0.68) were inversely associated to renal cancer. No association between flavonoids and prostate cancer emerged, whereas inverse association was found between proanthocyanidins and colorectal cancer. These associations appeared stronger for proanthocyanidins with a higher degree of polymerization (Rossi et al. 2010).

In the European Prospective Investigation into Cancer and Nutrition study (Nothlings et al. 2008), the intake of vegetables, legumes, and fruit was significantly associated with reduced risks of CVD mortality and mortality due to 
non-CVD/non-cancer causes $\quad\left[\begin{array}{lllll}R R & 0.88 & (95 \% & \text { CI }\end{array}\right.$ $0.81-0.95)$ and $0.90(0.82-0.99)$, respectively] in a diabetic population comprising $>10,000$ individuals. High urinary excretion of both equol and enterolactone (mammalian metabolite of plant lignans) has been found to be associated with a significant decrease in breast cancer risk in an epidemiological case-control study in breast cancer patients (Ingram et al. 1997). Although this could suggest the possible importance of isoflavonoid and lignan metabolism in decreased breast cancer risk, the phytoestrogen excretion observed may just be a marker of dietary differences (Barnes 1998). Knekt and co-workers also estimated that men with higher quercetin intake had a lower lung cancer incidence, and men with higher myricetin intakes had a lower prostate cancer risk (Knekt et al. 2002).

The intake of flavonoids is not inversely related with bladder cancer or breast cancer risk in some of the studies (Garcia-Closas et al. 1999; Peterson et al. 2003). Quercetin has been reported to prevent renal cell cancer among male smokers (Wilson et al. 2009). A case-control study conducted between 1994 and 2002 in four Italian areas to study the relation between major flavonoid classes and renal cell carcinoma by Bosetti et al. 2007 revealed that flavonols and flavones were inversely related to the risk of renal cancer. A cohort of 34,651 postmenopausal cancer-free women revealed inverse relation between catechin intake and rectal cancer (Arts et al. 2002).

Population-based case-control studies carried out separately in Hawaii, Uruguay and Spain suggested an inverse association between different cancers (oral cavity, pharynx, larynx and esophagus, lungs, stomach) and total intake of flavonoids, beta-carotene and vitamin E (Le Marchand et al. 2000; Stefani et al. 1999a, b; Garcia-Closas et al. 1999). Inverse association of cholangiocarcinomas (CAC) with flavan-3-ols, anthocyanidins and total flavonoids has been reported and flavones may be inversely associated with hepatocellular carcinoma cells (HCC) risk (Lagiou et al. 2008). A statistically significant association between highest flavonoid intake and reduced risk of developing lung cancer has been reported whereby an increase in flavonoid intake of $20 \mathrm{mg} /$ day was associated with a $10 \%$ decreased risk of developing lung cancer (Tang et al. 2009).

The studies on tea, flavonoids and lung cancer risk indicated a small beneficial association, particularly among never-smokers. More well-designed cohort studies are needed to strengthen the evidence on effects of long-term exposure to physiological doses of dietary flavonoids (Arts 2008). Consumption of soy foods rich in isoflavones has been weakly associated with reduced colon and prostate cancer (Adlercreutz 2002; Guo et al. 2004; Holzbeierlein et al. 2005; Goetzl et al. 2007). A protective effect of flavonoids in association with vitamin $\mathrm{C}$ has been shown on esophageal cancer using data from case-control study conducted in northern Italy (Rossi et al. 2007). Flavonoidrich diet may decrease pancreatic cancer risk in male smokers not consuming supplemental alpha-tocopherol and beta-carotene (Bobe 2008).

In vitro studies

Isoflavonoids have biphasic effects on the proliferation of breast cancer cells in culture; at concentrations $>5 \mathrm{mM}$, genistein exhibits a concentration-dependent ability to inhibit both growth factor-stimulated and estrogen-stimulated (reversed by $17 \mathrm{~b}$-estradiol) cell proliferation (So et al. 1997). Although genistein is a much better ligand for $E R b$ than for the ERa (20-fold higher binding affinity) (Kuiper et al. 1997), it can also act as an estrogen agonist via both $\mathrm{ERa}$ and ERb in some test systems (Kuiper et al. 1998; Mueller et al. 2004). Furthermore, although genistein binds to the ligand-binding domain of ERb in a manner similar to that observed for $17 \beta$-estradiol, in the ERb-genistein complex the AF-2 helix (H12) does not adopt the normal agonist type position, but instead takes up a similar orientation to that induced by ER antagonists such as raloxifene (Pike et al. 1999). This suboptimal alignment of the transactivation helix is in keeping with the reported partial agonist activity of genistein via ERb in human kidney cell (Barkhem et al. 1998).

Anti-cancer activity of methanolic flower extract of Tecoma stans (METS) was evaluated by both in vitro (Vero and Hep 2 cell lines) and in vivo (using Ehrlich ascites carcinoma tumor model) methods and compared with 5-flurouracil. A significant dose-dependent anti-tumor activity was indicated (Kameshwaran et al. 2012). Enriched ginger extract exhibited higher anti-cancer activity on MCF-7 breast cancer cell lines with IC 50 value 34.8 and $25.7 \mu \mathrm{g} / \mathrm{ml}$ for two varieties. IC50 values for MDA-MB231 were 32.5 and $30.2 \mu \mathrm{g} / \mathrm{ml}$ for rhizome extract of two varieties (Rahman et al. 2011). Luteolin-7-methyl ether isolated from leaves of Blumea balsemifera showed strong cytotoxicity against human lung cancer cell lines (NCIH187) with IC 50 of $1.29 \mu \mathrm{g} / \mathrm{ml}$ and moderate toxicity against oral cavity cancer cell lines (KB) with IC 50 of $17.83 \mu \mathrm{g} / \mathrm{ml}$ (Saewan et al. 2011).

In vitro and in vivo studies on anti-cancer activity of flavonoids isolated from a herbal formulation revealed IC 50 of $24.948,31.569$ and $6.923 \mu \mathrm{g} / \mathrm{ml}$, respectively, on three cancer cell lines MCF-7, Hep G-2 and ES-2 with dose-dependent inhibitory effect on hepatocellular carcinoma in mice (Liu et al. 2011). Broccolini leaf flavonoids (BLF) possess a dose-dependent anti-proliferative effects on four human cancer cell lines (SW480, HepG2, Hela, and A549) and apoptosis induction activity on SW480 cell line. Thus, the hybrid species Broccolini could be considered as a functional vegetable with potential in assisting for the 
treatment of four human cancers examined (Wang and Zhang 2012).

Apigenin inhibited skin papillomas and showed the tendency to decrease conversion of papillomas to carcinomas (Wei et al. 1990). Luteolin has been shown to penetrate into human skin, making it also a candidate for the prevention and treatment of skin cancer (Seelinger et al. 2008). Seufi et al. (2009) demonstrated that preventive effect of quercetin on hepato carcinomas in rats by RAPD-PCR, whereby, it was proved that quercitin exerted a preventive effect via decreased oxidative stress and decreased antioxidant activity. Dietary proanthocyanidins mostly present in apples, pears and pulses has been suggested to reduce the risk of pancreatic cancer by $25 \%$ (Rossi et al. 2010).

Ethanolic extract of propolis has been found to inhibit urinary bladder transitional cell carcinoma (TCC) cell proliferation with no cytotoxic effect on normal epithelial cells (Oršolić et al. 2010). Genistein inhibited the expression of micro-RNA 21 in A-498 (RCC) cells and in the tumors formed after injecting genistein treated A-498 cells in nude mice besides inhibiting tumor formation (Zaman et al. 2012).

Kaempferol, a dietary flavonoid is effective in reducing vascular endothelial growth factor (VEGF) expression in ovarian cancer cells. It enhances the effect of cisplatin through downregulation of $\mathrm{cMyc}$ in promoting apoptosis of ovarian cancer cells (Luo et al. 2010). The growth of U14 cervical cancer could be inhibited by Scutellaria baicalensis total flavonoids (STF), the cell proliferation inhibited by arresting cell cycle and cell apoptosis induced by regulating the expression of $\mathrm{Bax}$ and $\mathrm{Bcl}-2$ gene by treatment of STF (Peng et al. 2011). Some of the Indian medicinal plants like Ashwagandha, Curcumin, Lithosprmum radix, green tea, Chinese herb Astragalus and Japanese herb Juzen-Taiho-To have been reported to be effective against various cell lines of lung cancers (Ravichandiran et al. 2011). A comparison of cytotoxic effect of 11 flavonoids on chronic myeloid leukemia K562 cells and peripheral blood mononuclear cells indicated that baicalein and myricetin had a specific cytotoxic effect on leukemia cells (Romanouskaya and Grinev 2009).

Apoptotic activity of 22 flavonoids and related compounds in leukemic U937 cells were tested by Monasterio et al. (2004). They reported that flavones but none of the isoflavones induced the apoptotic cell death as determined by reduction in cell viability, flow cytometery and oligonucleosomal DNA fragmentation. The molecular consequences of apigenin treatment in myeloid and erythroid subtypes reveal the blocked proliferation of both cell lines through cell cycle arrest in different phases. JAK/STAT was one of the major target of apigenin but at the same time apigenin reduced susceptibility toward the commonly used therapeutic agent vincristine (Ruela-de-Sousa et al.
2010). A newly synthesized flavonoid III-10 could express anti-cancer effect on human U937 leukemia cell line through differentiation induction. The differentiation-related proteins phospholipids scramblase 1 (PLSCR1) and promyelocytic protein (PML) were upregulated after III-10 treatment through activation of protein kinase $\mathrm{C} \delta$ (Qin et al. 2012). Quercetin inhibited thyroid cell growth in association with inhibition of insulin-modulated-PI3Kinase-AKT kinase activity. It also decreased TSH-modulated RNA level of NIS (sodium iodide sympoter) gene and thereby suggested to be a novel disrupter of thyroid function which has potential uses in thyroid cancers (Giuliani et al. 2008). Chrysin inhibited proliferation of HTH 7 and KAT 18 (anaplastic thyroid cancer cell lines) in a dose and time-dependent manner. A significant increase in cleaved caspase- 3 , cleaved polyADP ribose polymerase (PARP) along with a decrease in cyclin D1, Mcl-1 and XIAP was observed (Phan et al. 2011). BNF ( $\beta$-napthoflavone) showed a moderate anti-proliferative activity in WHCO-6 cells and a weak activity in WHCO-1 cells. It resulted in differential expression of CYP1A1, CYP1A2 and CYP1B1 (Molepo 2010).

\section{In vivo studies}

In vivo studies using animal models have suggested the protective effect of flavonoids against initiation as well as tumor progression. Animal model studies have provided the initial experimental evidence that soy can prevent breast cancer (Barnes 1998; Messina et al. 1994). Fermented soy milk (rich in genistein and daidzein), given to rats at 7 weeks of age, inhibited mammary tumorigenesis induced by $\mathrm{PhIP}$ (2-amino-1-methyl-6-phenylimidazo [4,5-b] pyridine (Ohta et al. 2000). In syngenetic mice, i.p. administration of quercetin and apigenin inhibited growth and metastatic potential of melanoma cell (B16-BL6) along with significant decrease in their invasion in vitro (Caltagirone et al. 2000). A polymethoxy flavonoid, nobiletin, inhibited the tumor-invasive activity of human fibrosarcoma HT-1080 cells in the Matrigel model through suppressing the expression of metalloproteases and augmenting of production of tissue inhibitors of metalloproteinases in tumor cells (Sato et al. 2002). Furthermore, injection of prepubertal rats with genistein $(500 \mathrm{mg} / \mathrm{g}$ body weight $)$ or estradiol benzoate ( $500 \mathrm{ng} / \mathrm{g}$ body weight) on days 16,18 , and 20 showed that both treatments resulted in significantly increased mammary gland terminal end buds and increased ductal branching compared to controls, indicating an ERdependent action of genistein in mammary gland proliferation and differentiation, which could be protective against mammary cancer (Cotroneo et al. 2002). Overall, these results indicate that genistein has very complex effects on carcinogen-induced mammary cancer in the rat model and 
great care is required in interpreting these results and drawing parallels with human breast cancer. Equol has been found to be a novel anti-androgen that inhibits prostate growth and hormone feedback in rat studies (Lund et al. 2004). In nude mice with xenografted tumors using HAK1B hepatoma cells, luteolin significantly inhibited the growth of the tumors in a dosage-dependent manner by targetting STAT3 through dual pathways-the ubiquitindependent degradation in $\mathrm{Tyr}^{705}$-phosphorylated STAT3 and the gradual downregulation in $\mathrm{Ser}^{727}$-phosphorylated STAT3 through inactivation of CDK5, thereby triggering apoptosis via upregulation in Fas/CD95 (Selvendiran et al. 2006). A flavonoid rich fraction (Fr-6) and a more purified proanthocyanidin (PAC) were isolated from cranberry and both fractions are found to slow the growth of explant tumor U87 in vivo, PAC inhibited growth of HT-29 and DU145 explants $(p<0.05)$, inducing complete regression of two DU145 tumor explants (Ferguson et al. 2004). A covalent conjugate of artemisinin (flavonoid from Artemisia annua) and transferrin (ART-Tf), an iron transport protein in human, are actively taken up by cancer cells through the transferrin receptor (TfR)-mediated endocytosis pathway, and show significantly higher anti-cancer activity than unconjugated artemisinin (Lai et al. 2005; Nakase et al. 2009). Like ART-Tf, artemisinin-peptide conjugates that are designed to target TfR also showed highly potent and selective anti-cancer activities (Oh et al. 2009). Although the generation of free radicals originating from the reaction of artemisinin with molecular iron is mentioned as one of the main mechanism for its anti-cancer activity, there are other mechanisms, crucial for cancer proliferation and survival that are affected by artemisinins. These mechanisms have been described in a current review (Firestone and Sundar 2009; Ferreira et al. 2010). Mammographic breast density can be used as biomarker of estrogenic or anti-estrogenic effects of a particular treatment on breast tissue (Atkinson et al. 2004). Consumption of a dietary supplement that provided red clover-derived isoflavones (26 mg biochanin A, $16 \mathrm{mg}$ formononetin, $1 \mathrm{mg}$ genistein, and $0.5 \mathrm{mg}$ daidzein) for 12 months did not increase mammographic breast density in postmenopausal women, suggesting neither estrogenic nor anti-estrogenic effects, of this supplement at the dose given, on the breast (Atkinson et al. 2004). Honeybee propolis and its polyphenolics exerted an anti-metastatic anti-tumor effect in mice and rats and considerable cytotoxicity without cross resistance in both wild-type and chemoresistant human tumor cell lines suggesting these to be potent adjunct to chemotherapy and radiotherapy in treatment of cancers (Oršolić et al. 2010). Colon cancer risk is influenced by estrogen exposure; studies with estrogen receptor $\alpha$ knockout mice indicate that it may be independent of estrogen receptor $\alpha$ (Guo et al. 2004). Furthermore, in vivo studies in male rats have shown that genistein decreases the amount of EGF receptor present in the prostate, indicating that the observed decrease in tyrosine phosphorylation may be only a secondary effect of the influence of genistein on the expression or turnover of EGF receptor (Dalu et al. 1998). Luteolin can delay or block the development of cancer cells in vitro and in vivo by protection from carcinogenic stimuli, by inhibition of tumor cell proliferation, by induction of cell cycle arrest and by induction of apoptosis via intrinsic and extrinsic signaling pathways. When compared to other flavonoids, luteolin was usually among the most effective ones, inhibiting tumor cell proliferation with IC50 values between 3 and $50 \mu \mathrm{M}$ in vitro and in vivo by $5-10 \mathrm{mg} / \mathrm{kg}$ i.p., intragastric application of $0.1-0.3 \mathrm{mg} / \mathrm{kg} / \mathrm{d}$, or as food additive in concentrations of 50-200 ppm (Seelinger et al. 2008).

\section{Molecular mechanism of anti-cancer effect}

Flavonoids have been very often pointed out as in vitro enzyme inhibitors and ligands of receptors involved in signal transduction (Middleton and Kandaswami 1994; Havsteen 2002; Williams et al. 2004; Brown et al. 2007; Balasuriya and Rupasinghe 2011). So these flavonoidprotein interactions together with their anti-oxidant properties are the key features for their potential health benefits. Furthermore, some effects may be a result of a combination of radical scavenging and interaction with enzyme functions. The phenolic nucleus is a structural unit that is favorable to molecular (non-covalent) interactions with proteins.

These interactions can be either Vander wall or electrostatic interactions. In former type, the non-polar polarizable aromatic ring can develop strong dispersion interactions with non-polar amino acid residues followed by simultaneous release of water; while in later type, H-bonding is the most important electrostatic interaction. Flavanoid-protein redox reactions and oxidative covalent coupling may result fom one-or two-electron oxidation of the flavonoid brought about by autooxidation, scavanging of reactive oxygen species and enzymatic oxidation. For some conformationally open proteins (e.g. salivary proteins), binding constants are quite low with polyphenols but polymerization and condensation of these polyphenols produces an increase in affinity (Kurisawa et al. 2003; Kim et al. 2004). It can be due to unspecific binding along an extended protein chain or at the surface of globular proteins (Haslam 1996; Spencer et al. 1988; Xi and Guo 2008).

Inhibition of $\mathrm{PK}_{\mathrm{s}}$

Phosphorylation of proteins at $\mathrm{OH}$ groups of serine, threonine, and tyrosine residues is an important mechanism of 
intracellular signal transduction involved in various cellular responses including the regulation of cell growth and proliferation (Birt et al. 2001; Bridges 2001). The reaction makes use of ATP as a phosphate donor and is catalyzed by protein kinases. For instance, growth factor hormones bind to extracellular domains of large transmembrane receptors that display a tyrosine kinase moiety in their intracellular portion. As a consequence of hormone-receptor binding, the receptor dimerizes and becomes active in the phosphorylation of proteins close to the membrane, thereby triggering a large number of signaling pathways themselves involving other PKs, such as PKC, a Ser/Thr PK, and mitogen-activated PKs (MAPKs). On the other hand, each phase of the cell cycle, during which the DNA is replicated and the chromosomes built and then separated, is characterized by intense bursts of phosphorylation controlled by highly regulated kinases called cyclin-dependent kinases (CDKs). A possible mechanism for the potential anti-carcinogenic effects of flavonoids could be their ability to inhibit various PKs, thereby inhibiting signal transduction event of cell proliferation.

The isoflavone genistein has been shown to inhibit the epidermal growth factor (EGF) receptor in the submicromolar range by competing with ATP for its binding site (Rudrabhatla and Rajasekharan 2005; Akiyama et al. 1987). Similarly, butein $\left(2^{\prime}, 3,4,4^{\prime}\right.$-tetrahydroxychalcone) appears as a specific inhibitor of tyrosine kinases (IC50 for EGF receptor $1 / 465 \mathrm{mM}$ ) acting competitively to ATP and non-competitively to the phosphate acceptor and having no affinity for Ser/Thr PKs such as PKC and the cAMPdependent PKA (Yang et al. 1998, 2006).

Recently, PKC was shown to be efficiently inhibited by flavones and flavonols having a 3',4'-dihydroxy substitution on the $\mathrm{B}$ ring (efficient concentrations 50 in the range 1-10 mM) (Agullo et al. 1997; Gamet-Payrastre et al. 1999) phosphoinositide 3-kinase (PI3-K), a lipid kinase catalyzing phosphorylation of inositol lipids at the D3 position of the inositol ring to form new intracellular lipid second messengers (Gamet-Payrastre et al. 1999) is also inhibited by flavonoids.

Consistently, studies with intact cells have shown that various flavonoids can cause cell cycle arrest in correlation to their ability to inhibit CDKs ( $\mathrm{Zi}$ et al.1998; Casagrande and Darbon 2001). Flavonoids can also modulate the activity of MAPKs as a possible mechanism for their potential anti-neurodegenerative action (Schroeter et al. 2001, 2002) and protection against autoimmune, allergic, and cardiovascular diseases (Yoshizumi et al. 2002; Ahn et al. 2004). For instance, investigations on intact antigenpresenting dendritic cells have shown that the MAP kinases involved in cell maturation (ERK, p38 kinase, JNK) can be activated by bacterial lipopolysaccharide and that this activation is strongly inhibited by pretreatment of the cells by EGCG.61 However, no evidence is provided that the mechanism actually proceeds via direct EGCG-MAPK inhibition.

\section{Inhibition of prooxidant enzymes}

Formation of reactive oxygen species (ROS) is a major step in the tumor promotion and progression stages. The involvement of ROS in tumor progression has been demonstrated in human cells. NADPH oxidase I (NOX 1), an enzyme that produces superoxide is overexpressed in colon and prostate cancer cell lines (Fukuyama et al. 2005; Lim et al. 2005), while its downregulation reverses tumor growth (Arnold et al. 2007). ROS play important role in DNA damaging and mutagenic signaling (Poli et al. 2004; Valko et al. 2004). ROS act as secondary messenger in several pathways that lead to increase in cell proliferation, resistance to apoptosis, activation of proto-oncogenes such as cFOS, cJUN and cMyc. In human hepatoma cells, ROS modulate the expression of cFOS and cJUN through PKB pathway (Liu et al. 2002).

Lipoxygenases (LOX), cycloxygenases (COXs), and xanthine oxidase (XO) are metalloenzymes whose catalytic cycle involves ROS such as lipid peroxyl radicals, superoxide, and hydrogen peroxide. LOXs and COXs catalyze important steps in the biosynthesis of leucotrienes and prostaglandins from arachidonic acid, which is an important cascade in the development of inflammatory responses. XO catalyzes the ultimate step in purine biosynthesis, i.e., the conversion of xanthine into uric acid. XO inhibition is an important issue in the treatment of gout. Flavonoids may exert part of their anti-oxidant and anti-inflammatory activities via direct inhibition of these prooxidant enzymes (LOXs, COXs, and XO). Similarly, flavonoids can inhibit ornithine decarboxylase (rate-limiting enzyme in polyamine biosynthesis) induced by tumor promoters, and thereby inhibiting proliferation. Typically, interpretation of the inhibition studies is complicated because of the possible combination of distinct inhibition mechanisms: formation of non-covalent enzyme-inhibitor complexes, direct scavenging by flavonoid anti-oxidants of ROS inside or outside the catalytic pocket (with simultaneous oxidation of the flavonoids), chelation of the enzyme metal centers by the flavonoids, and enzyme inactivation by reactive aryloxyl radicals, quinones, or quinonoid compounds produced upon flavonoid oxidation that may eventually form covalent adducts with the enzyme (Olivier and Claire 2005; Sandhar et al. 2011).

Modulate the metabolism of carcinogen

Activation of a procarcinogen to carcinogen is an important step in carcinogenesis and can be modulated by flavonoids. 
Flavonoids can exert their effect by two possible mechanisms. Firstly, by interacting with phase 1 enzymes $\left(\mathrm{CyP}_{450}\right)$ that are involved in metabolic activation of procarcinogens. Second mode of action can be the detoxification and elimination of carcinogens via induction of phase II enzymes such as UDP-glucuronyl transferase, quinone reductase and glutathione $S$-transferase.

These heme-containing cytochrome P450 (CYP) monooxygenases include several isoforms (CYP 1A1, 1A2, $1 \mathrm{~B} 1,3 \mathrm{~A} 4,3 \mathrm{~A} 5$, etc.) with different tissue distributions and play a key role in the metabolism of endogenous substrates (e.g., steroids) and xenobiotics (food components, drugs, carcinogens, pollutants) (Anzenbacher and Anzenbacherová 2011; Hodek et al. 2002; Ahmad and Mukhtar 2004). Indeed, CYPs are responsible for the conversion of some procarcinogens (e.g., polyaromatic hydrocarbons or PAHs) into carcinogens (e.g., PAH epoxides). Cytochrome P450 enzymes are a good example of proteins whose function can be regulated by flavonoids via such diverse mechanisms (Hodek et al. 2002, 2009).

CYP-flavonoid interactions are a good example of the multiple ways flavonoids can affect enzymatic activities, i.e., from the regulation of gene expression to direct binding to the processed enzymes. Flavonoids can induce, or eventually inhibit, the biosynthesis of CYP $1 \mathrm{~A} 1$ via interactions with the aryl hydrocarbon receptor (AhR), a cytosolic protein that, once activated by a ligand, translocates to the nucleus and, in association with the AhR translocator, forms a transcription factor for CYP 1A1. For instance, in human breast cancer cells, quercetin binds to $\mathrm{AhR}$ as an agonist and stimulates gene expression for CYP $1 \mathrm{~A} 1$ with a parallel increase in CYP 1A1-mediated $O$ deethylation of 7-ethoxyresorufin (Ciolino et al. 1999). This process is strikingly dependent on the hydroxylation pattern of the B ring since kaempferol ( $3^{\prime}$-deoxyquercetin) binds $\mathrm{AhR}$ as an antagonist (no subsequent activation of CYP 1A1). It is also highly dependent on the cell type since, in hepatic cells, quercetin binds to AhR as an antagonist, thereby inhibiting gene expression for CYP $1 \mathrm{~A} 1$ and benzo[a]pyrene activation (Kang et al. 1999). This provides a possible mechanism for the anti-cancer activity of quercetin. Flavonoids, especially flavones and flavonols, also directly bind to several CYP isoforms (1A1, 1A2, 1B1, 3A4) involved in xenobiotics metabolism and inhibit enzyme activity. Structure-activity relationships (Doostdar et al. 2000) show rather high isoform selectivities depending on the flavonoid substitution pattern and contrasted inhibition mechanisms. Finally, flavonoids are also able to inhibit CYP19 or aromatase, an enzyme catalyzing a three-step oxidation sequence resulting in aromatization of the A ring of male steroid hormones (androgens) to yield estrogens. Together with flavonoid-estrogen receptor binding, this process could be relevant to the prevention of hormone-dependent breast cancer by flavonoids (Brueggemeier et al. 2001).

Interestingly, $17 \beta$-hydroxysteroid dehydrogenase, another redox enzyme involved in steroid metabolism, is also strongly inhibited by 7-hydroxyflavonoids (Le Bail et al. 1998). For instance, the flavone apigenin is more potent at inhibiting 17b-hydroxysteroid dehydrogenase (IC50 $1 / 40.3 \mathrm{mM}$ ) than aromatase (IC50 $1 / 42.9 \mathrm{mM}$ ) and the isoflavone genistein, which is only a weak aromatase inhibitor, inhibits 17b-hydroxysteroid dehydrogenase with an IC50 of $1 \mathrm{mM}$. The flavonols quercetin, kaempferol, myricetin, the flavone apigenin, and the biflavone biapigenin were also reported to inhibit CYP3A4 activity at low micromolar concentrations in human liver microsomes (von Moltke et al. 2004).

Xenobiotics, drugs and flavonoids follow the same course of metabolism. As these compounds are hydrophobic in nature, so the first step involving the conjugation of these drugs to increase their hydrophilicity is a key step in their metabolism. This step is performed by the above mentioned phase-II enzymes. Flavonoids have been demonstrated to activate these enzymes and thereby increase detoxification and elimination of carcinogens from the body. UDPglucuronosyltransferases (UGT) use UDP-glucuronic acid as a cosubstrate and transfer glucuronic acid to available substrates thereby making them more water soluble and facilitating their excretion in the urine or bile. Similarly, sulfotransferases (SULT) catalyze the transfer of a sulfonate group, glutathione $S$-transferases (GST) transfer glutathione and $\mathrm{N}$-acetyltransferases transfer acetyl moiety to an appropriate substrate. It has been shown that all these phase II enzymes are affected by flavonoids in cell and animal models.

An increase in mRNA levels, protein expression and enzyme activity of UGT isoform 1A1 has been reported in human Hep G2 cells and human colon carcinoma cells by chrysin, apigenin, baicalein, diosmetin, quercetin and kaempferol (Galijatovic et al. 2001; Walle and Walle 2002; Sugatani et al. 2004). van der Logt et al. 2003 reported an increase in UGT activity in intestine and liver by feeding rats on a diet containing $1 \% \mathrm{wt} / \mathrm{wt}$ quercetin and $0.5 \% \mathrm{wt} /$ wt flavones. Quercetin significantly increased UGT1A1 mRNA in shed enterocytes on in vivo perfusion of human jejunam and in Caco-2 cells (Petri et al. 2003). A number of flavonoids including fisetin, galangin, quercetin, kaempferol, and genistein represent potent non-competitive inhibitors of sulfotransferase 1A1 (or P-PST); this may represent an important mechanism for the chemoprevention of sulfation-induced carcinogenesis (Moon et al. 2006). Dietary intake of citrus limonoids (Perez et al. 2010) may provide a protective effect against the onset of various cancers by inducing the activity of certain phase II detoxifying enzymes [glutathione $S$-transferase and $\mathrm{NAD}(\mathrm{P}) \mathrm{H}$ : 
quinone reductase] in specific organs. Johnson et al. (2009) analyzed the ability of eriodictyol to activate $\mathrm{Nrf} 2$ and induce the phase II proteins, heme-oxygenase (HO-1), $\mathrm{NAD}(\mathrm{P}) \mathrm{H}$ : quinone oxidoreductase 1 (NQO-1), and the cellular anti-oxidant glutathione, GSH. They have shown that ARPE-19 cells that overexpress HO-1 or NQO-1 were more resistant to oxidative stress-induced cell death than control cells. Cermak (2008) reviewed flavonoids as potent inhibitors of cytosolic SULT isoforms. Quercetin inhibited sulfation of 4-nitrophenol and of several drugs including salbutamol, minoxidil, paracetamol, apomorphine in human liver cytosol (De Santi et al. 2002; Marchetti et al. 2001; Vietri et al. 2002). Quercetin significantly affected the activity of hepatic GST, whereas dietary catechin significantly changed $\mathrm{NAD}(\mathrm{P}) \mathrm{H}$ quinone oxidoreductase-1 activity (26\%) in rats. Changes in GST and NAD(P)H quinone oxidoreductase-1 activity were partly reflected on mRNA levels (Wiegand et al. 2009).

Inhibition of multidrug resistance

Cancer cells typically overexpress P-glucoprotein (Pgp) or multidrug resistance associated protein (MRP) which is ATP-dependent transmembrane transporters capable of expelling a wide variety of chemically unrelated drugs used in cancer therapy at the expense of ATP hydrolysis. This phenomenon is known as multidrug resistance (MDR) and inhibition of MDR, to prevent drug efflux has potential clinical application during cancer therapy.

Quercetin was shown to efficiently inhibit the Pgpmediated drug efflux by inhibiting the overexpression of human MDR1 gene (Kioka et al. 1992) and by inhibiting the ATPase activity required for transport (Shapiro and Ling 1997). From investigations using a soluble cytosolic portion of mouse Pgp, which includes the nucleotide- and drug-binding domains, it was possible to monitor flavonoid binding by fluorescence as well as its influence on ATP binding and the efflux of the anti-cancer steroid drug RU 486 (Conseil et al. 1998). Flavones (aglycones) bearing $\mathrm{OH}$ groups at positions 3 and 5 come up as efficient mouse Pgp ligands with apparent dissociation constants lower than $10 \mathrm{mM}$. By contrast, the quercetin glycoside rutin, the flavanone naringenin, and the isoflavone genistein have low affinity for Pgp. Interestingly, flavones and flavonols behave as bifunctional inhibitors whose binding site overlap the vicinal binding sites for both ATP and RU 486. Those trends were confirmed using a cytosolic portion of Pgp from the parasite Leishmania tropica (Perez-Victoria et al. 1999). Flavonoids have been reported to inhibit ATPase activity, nucleotide hydrolysis and energy-dependent drug interaction with transporter enriched membranes (Di Pietro et al. 2002). This unique property of reversal of MDR has been found to enhance doxorubin (DOX)- induced anti-tumor activity by increasing the DOX concentration at target site (Blagosklonny 2001). To study that how epicatechin gallate, epigallocatechin gallate, genistein, genistin, naringenin, naringin, quercetin and xanthohumol will modulate cellular uptake and permeability $[\mathrm{P}(\mathrm{e})]$ of multidrug-resistant substrates, cyclosporin A (CSA) and digoxin, across Caco-2 and MDCKII-MDR1 cell-transport models, uptake experiments were perfomed with and without flavonids. Aglycone flavonoids reduced the $\mathrm{P}(\mathrm{e})$ of CSA to a greater extent than that of digoxin, suggesting that transport mechanism of CSA can be different from digoxin (Rodriguez-Proteau et al. 2006). Ofer et al. (2006) compared the potency of quercetin, isoquercitin, spiraeoside, rutin, kaempferol, naringenin, naringin and hesperetin to inhibit the transport through P-gp transporters (substrate ${ }^{3} \mathrm{H}$-talinolol) and OCT (substrate ${ }^{14} \mathrm{C}$-TEA) of Caco- 2 cells and LLC-PK 1 cells, respectively. Six of the investigated flavonoids reduced the secretory flux of talinolol across Caco- 2 cells but none of the selected flavonoids was able to replace ${ }^{3} \mathrm{H}$-talinolol from its binding to $\mathrm{P}$-gp. This might be due to an interaction with $\mathrm{P}-\mathrm{gp}$, but apparently not via competition at the talinolol binding site of P-gp. The investigated flavonoids did show potency to inhibit OCTmediated transport (IC50-values: quercetin $<$ kaempferol $\ll$ naringenin $<$ isoquercitrin $<$ spiraeoside $\ll$ rutin $<$ hesperetin $<$ naringin) may be by the inhibition of members of the OCT family.

This flavonoid-ABC-transporter interaction could be beneficial for poorly absorbed drugs but could also result in severe drug intoxication, especially drugs with a narrow therapeutic window (Alvarez et al. 2010). Most of the studies have demonstrated inhibitory effects of flavonoids on the substrate efflux in cells that either endogenously expressed these transporters or that were transfected with them (Morris and Zhang 2006). These ABC-transporter proteins can affect the oral availability and tissue distribution of the flavonoids also, thereby modifying their beneficial effects (Brand et al. 2006).

\section{Anti-oxidant properties}

In addition to enzymatic oxidation, flavonoid oxidation can take place via autoxidation (metal-catalyzed oxidation by dioxygen) and ROS scavenging. The former process can be related to flavonoid cytotoxicity (ROS production) while the latter is one of the main anti-oxidant mechanisms. Both processes may be modulated by flavonoid-protein binding. Although poorly documented so far, these points could be important and, for instance, albumin-flavonoid complexes with an affinity for LDL could act as the true plasma antioxidants participating in the regeneration of $\alpha$-tocopherol from the $\alpha$-tocopheryl radical formed upon scavenging of LDL-bound lipid peroxyl radicals. In addition, flavonoid- 
protein complexation can be expected to provide protection to the protein against oxidative degradation.

Since lipid peroxidation is clearly related to the onset of atherosclerosis and the impairment of membrane functions, the influence of proteins on the ability of flavonoids to inhibit lipid peroxidation deserves examination (Peng and Kuo 2003; Liu et al. 2006; Kumar et al. 2008; Li 2011). Such investigations have been carried out with BSA and lecithin liposomes (Heinonen et al. 1998; Sivonová et al. 2006). Whereas BSA alone already slows down the formation of lipid hydroperoxides and hexanal, its influence on the anti-peroxidizing activity of the selected polyphenols is highly dependent on the polyphenolic structure. Hence, BSA lowers the inhibition of hydroperoxide formation by catechins and caffeic acid, enhances inhibition by malvidin and rutin, and leaves essentially unchanged inhibition by quercetin. No clear interpretation based on polyphenol-BSA binding can be given. One-electron oxidation of protein-bound phenols to form reactive aryloxyl radicals is a possible pro-oxidant mechanism, since these radicals can propagate $\mathrm{H}$-atom or electron transfers within the protein. In addition to phenol-protein covalent coupling, these phenol-mediated oxidative damages to proteins could be detrimental to their function as enzymes, receptors, and membrane transporters.

Anti-oxidant properties have been reported for isoflavones both in vitro and in vivo (Wei et al. 1995; Wiseman et al. 1998, 2000; Mitchell et al. 1998). Equol, in model membrane systems, was a more effective anti-oxidant than genistein or the parent compound daidzein (Wiseman et al. 1998) and shows structural similarity to the tocopherols. Daidzein and geinstein showed anti-oxidant action in primary and cancer lymphocytes (Jurkat cells), both isoflavones increased DNA protection against oxidative damage and decreased lipid peroxidation (Foti et al. 2005). Moreover, a protective effect was achieved at concentrations that can be achieved in plasma following soy consumption. An important aspect of cancer risk is the involvement of the inflammatory response, which involves the production of cytokines and proinflammatory oxidants such as the hypochlorous acid produced by neutrophils and peroxynitrite by macrophages, which react with phenolic tyrosine residues on proteins to form chloro- and nitrotyrosine (D'Alessandro et al. 2003). It has been reported that neutrophil myleloperoxidase chlorinates and nitrates isoflavones and enhances their anti-oxidant properties, thus soy isoflavones may have potentially protective benefits at sites of inflammation (D'Alessandro et al. 2003). Anti-oxidant action could also contribute to anti-cancer ability because ROS could initiate signal transduction through the mitogen-activated protein (MAP) kinases (Wiseman and Halliwell 1996). There have been a number of reports relating to the possible anti-oxidant effects of isoflavone consumption. Soy isoflavone consumption as a soy protein burger $(56 \mathrm{mg}$ isoflavones/day for 17 days) decreased plasma F2-isoprostane concentrations in healthy young adults (Wiseman et al. 2000). Consumption of a soy isoflavone supplement $(50 \mathrm{mg}$ isoflavones, twice a day for 3 weeks) decreased a biomarker of DNA oxidative damage (white cell 5-hydroxymethyl-2'-deoxyuridine concentrations) but did not alter plasma F2-isoprostane concentrations (Djuric et al. 2001). Furthermore, consumption of soy protein $(110 \mathrm{mg}$ isoflavones/day for 4 weeks) decreased plasma peroxide concentrations and increased total antioxidant status but did not effect a biomarker of oxidative DNA damage (Bazzoli et al. 2002). It is of considerable interest that widely differing effects in relation to the potential benefits to human health are frequently reported for isoflavones consumed within the food matrix in soy foods, compared to those consumed in capsule or tablet form as dietary supplements.

\section{Anti-angiogenesis}

Angiogenesis, the formation of new blood vessels, is an important process which is regulated by endogenous angiogenic and angiostatic factors. Any alteration in this tightly regulated process can lead to a persistent and uncontrolled growth and metastasis of tumors. Flavanoids have been reported as angiogenesis inhibitors (Tosetti et al. 2002). These inhibitors can cause lack of diffusion of nutrients and oxygen to rapidly growing cancerous cells due to anti-angiogenic properties and hence lead to cell death. Angiogenesis inhibitors can interfere with various steps in angiogenesis, such as the proliferation and migration of endothelial cells and lumen formation. A possible mechanism could be inhibition of protein kinases (Oikawa et al. 1992). These enzymes are implicated to play an important role in signal transduction and are known for their effects on angiogenesis. Genistein is a potent inhibitor of angiogenesis in vitro (Fotsis et al. 1993; Kim 2003; Su et al. 2005) and thus could have therapeutic applications in the treatment of chronic neovascular diseases including solid tumor growth (Fotsis et al. 1995) and inhibition of neovascularization of the eye by genistein has been reported (Kruse et al. 1997; Joussen et al. 2000; Xu and Yuan 2009). Studies on the inhibition of cell proliferation and angiogenesis by flavonoids in six different cancer cell lines had been reported and noted that the IC50 of active flavonoids were in the low micromolar range, physiologically available concentrations (Fotsis et al. 1997). Isoflavonones (genistein, genistin, daidzein, and biochanin A) also inhibit growth of murine and human bladder cancer cell lines by inducing cell cycle arrest, apoptosis, and angiogenesis (Zhou et al. 1998). Luteolin has been found to inhibit VEGF-induced angiogenesis; inhibition of endothelial cell survival and 
proliferation by targeting phosphatidylinositol-3-kinase action (Bagli et al. 2004). Favot et al. (2003) suggested the involvement of cyclin-dependent pathway in the inhibitory effect of delphinidin on angiogenesis. During the last decade, some more novel molecular targets for the inhibition of angiogenesis by genistein have been discovered including tissue factor, endostatin, and angiostatin ( $\mathrm{Su}$ et al. 2005).

Genistein may enhance the action of transforming growth factor- $\beta$ (TGF- $\beta$ ) (Kim et al. 1998; Sathyamoorthy et al. 2005). This action may be a link between the effects of genistein in a variety of chronic diseases (Barnes 1998) including atherosclerosis and hereditary hemorrhagic telangiectasia (the Osler-Weber-Rendu syndrome) in which defects in TGF- $\beta$ have been characterized (Johnson et al. 1996). Schindler and Mentlein (2006) determined whether secondary plant constituents, i.e., flavonoids, tocopherols, curcumin, and other substances regulate VEGF in human tumor cells in vitro. It was found that the glycosylated flavonoids (i.e., naringin, a constituent of citrus fruits, and rutin, a constituent of cranberries) induced the greatest response to treatment at the lowest concentration in MDA human breast cancer cells. Inhibition of VEGF release by flavonoids, tocopherols, and lovastatin in models of neoplastic cells suggests a novel mechanism for mammary cancer prevention. He et al. (2011) indicate that hispidulin targets the VEGF receptor 2-mediated PI3K/Akt/mTOR signaling pathway in endothelial cells, leading to the suppression of pancreatic tumor growth and angiogenesis.

Induce apoptosis and cell cycle arrest

Apoptosis is a programed cell death to eliminate damaged or unwanted cells. It is regulated by a variety of genes that can either promote apoptosis or can favor cell survival in response to internal or external stimuli. Dysregulation of apoptosis could play a critical role in oncogenesis. Among these genes, the tumor suppressor p53 plays a pivotal role in controlling the cell cycle, apoptosis, genomic integrity, and DNArepair (Bode and Dong 2004) by acting as transactivator or as transrepressor (Ho et al. 2005). After activation, p53 can bind to regulatory DNA sequences and activate the expression of genes involved in cell cycle inhibition (p21, reprimo, cyclin G1, GADD45), apoptosis (PERP, NOXA, PUMA, p53AIP1, ASPP1/2, Fas, BAX, PIDD) and genetic stability (p21, DDB2, MSH2, XPC) (Carr 2000; Amin et al. 2009). EGCG also activated p53 and BAX in breast carcinoma cells (Roy et al. 2005). Genistein induced G2/M arrest and apoptosis in human malignant glioma cell lines by activating p53 and p21 (Schmidt et al. 2008). In addition to p53, mammalian cells contain two closely related proteins, p63 and p73. EGCG induces apoptosis by activating p73-dependent expression of a subset of p53 target genes (Amin et al. 2007).
Nuclear factor-kappa B (NF-кB) family of transcription factors consists of five members, p50, p52, p65 (Rel A), c-Rel, and Rel B, which share an N-terminal Rel homology domain responsible for DNA binding. NF-кB is activated by free radicals, inflammatory stimuli, cytokines, carcinogens, tumor promoters, endotoxins, $\gamma$-radiation, ultraviolet (UV) light, and X-rays and induces NF-кB target genes important for cellular growth and transformation, suppression of apoptosis, invasion, metastasis, chemoresistance, radioresistance, and inflammation. Flavonoids may block one or more steps in the NF-KB signaling pathway such as inhibition of the most upstream growth factor receptors that activate the $\mathrm{NF- \kappa B}$ signaling cascade, translocation of NF-KB to the nucleus, DNA binding of the dimers, or interactions with the basal transcriptional machinery (Ju et al. 2007). The NF-кB target genes influenced by the flavonoids include inhibition of Bcl-2 and Bclx(L), cyclin D1, matrix metalloproteinases (MMP), and VEGF (Hastak et al. 2003; Li et al. 2006).

Flavonoids have been found to suppress activator protein-1 (AP-1) activation and modulate AP-1 target genes. AP-1 is a group of dimeric leucine zipper proteins consisting of Jun (c-Jun, JunB, JunD), Fos (c-Fos, FosB, Fra-1, and Fra-2), Maf (c-Maf, MafB, MafA, MafG/F/K, and Nrl), and ATF (ATF2, LRF1/ATF3, B-ATF, JDP1, JDP2) subfamilies (Shaulian and Karin 2002). These proteins form either homo- or heterodimers and bind either to AP-1 DNA recognition elements $\left(5^{\prime}-\mathrm{TGAG} / \mathrm{CTCA}-3^{\prime}\right)$ or to cAMP response elements $\left(5^{\prime}-\right.$ TGACGTCA- $\left.3^{\prime}\right)$ and activate their target genes. Some of the biologic effects of AP-1 are mediated by gene repression. AP-1-regulated genes include important modulators of invasion and metastasis, angiogenesis, proliferation, differentiation, and survival.

Activation of various tyrosine kinases leads to phosphorylation, dimerization, and nuclear localization of the signal transducers and activators of transcription (STAT) proteins, binding to specific DNA elements and direct transcription. Constitutive activation of STAT3 and STAT5 has been implicated in multiple myelomas, lymphomas, leukemias, and several solid tumors. Selvendiran et al. (2006) reported that luteolin inhibited phosphorylation of STAT3, which targeted it for proteosomal degradation and inhibited the expression of cyclin D1, survivin, $\mathrm{Bcl}-\mathrm{x}(\mathrm{L})$, and VEGF.

Luteolin is capable of inducing anti-cancer effects by inducing cell cycle arrest or apoptosis in oral squamous cancer cells (Yang et al. 2008), human esophageal, lung, liver and colon cancer cells (Zhang et al. 2008; Ju et al. 2007). Luteolin inhibited proliferation and induced apoptosis of prostate cancer cells in vitro and in xenografts (Chiu and Lin 2008), with increased efficacy of cisplatin in gastric cancer cells (Wu et al. 2008). Genistein inhibited $P$ Ca cell growth in culture by inducing G2/M arrest and 
apoptosis, increased the radiation efficacy against prostate cancer in cell culture and in vivo models (Lakshman et al. 2008)

Quercetin has been reported to suppress the viability of HeLa cells in a dose-dependent manner by inducing G2/M phase cell cycle arrest and mitochondrial apoptosis through a p53-dependent mechanism (Vidya et al. 2010). Some characteristic changes in nuclear morphology, phosphatidylserine externalization, mitochondrial membrane depolarization, modulation of cell-cycle regulatory proteins and $\mathrm{NF}-\kappa \mathrm{B}$ family members, upregulation of proapoptotic Bcl-2 family proteins, cytochrome C, Apaf-1 and caspases, and downregulation of anti-apoptotic Bcl-2 proteins and surviving was reported. Similarly fisetin inhibited the proliferation of bladder cancer cells by inducing apoptosis and blocking cell-cycle progression in the G0/G1 phase. It significantly increases the expression of p53 and p21 proteins, and decreases the levels of cyclin D1, cyclin A, CDK4 and $\mathrm{CDK} 2$, thereby contributing to cell cycle arrest. In addition, fisetin increased the expression of Bax and Bak but decreased the levels of Bcl-2 and Bcl-xL and subsequently triggered mitochondrial apoptotic pathway (Li et al. 2011a, b). Pretreatment with chrysin could increase TRAILinduced degradation of caspase 3, caspase 8, PARP protein. Z-VAD- fmk, which is a pan-cascade inhibitor, could inhibit the apoptosis enhanced by combination of chrysin and TRAIL (Li et al. 2011a, b). 2,2 dihydroxychalcone (DHC) and fisetin, induced S and G2 phase cell-cycle arrest in LNCaP and PC3 prostate cancer cells by downregulation in gene expression of 75 key cell cycle (G2 and M phases) and enhanced expression of 50 stress response gene. Thereby, DHC and fisetin induced apoptosis, but not accelerated senescence in prostate cells (Haddad 2008). The study on diethyl 5,7,4'-trihydroxy flavanone $N$-phenyl hydrazone (N101-2), a synthesized naringenin derivative exhibited cervical cancer cell growth inhibition by arresting the cell cycle at sub-G1 phase, activating mitochondriaemanated intrinsic and Fas-mediated extrinsic signaling pathways, and inhibiting the PI3K/AKT pathway in CaSki and SiHa human cervical cancer cells (Kim et al. 2012).

\section{Summary and conclusions}

Flavonoids greatly influence the cascade of immunological events associated with the development and progression of cancer. One has to understand the mechanism how these flavonoids get accumulated in cellular organelles and tissues once they enter inside. Flavonoids have the potential of modulatng many biological events in cancer such as apoptosis, vascularization, cell differentiation, cell proliferation, etc. A strong correlation persists between flavonoid-induced modulation of kinases with apoptosis, cell proliferation and tumor cell invasive behavior in vitro. Also, some of the dietary flavonoids have been known to display in vivo anti-tumor activity and repress in vivo angiogenesis. The cross talk between flavonoids and the key enzymes related to neoplastic cells and metastasis has to be understood in vitro and in vivo as well, providing new insights for fighting against cancer.

Conflict of interest The authors of the MS entitled "Anti-Cancer potential of Flavonoids: Recent Trends and Future Perspectives" declare that they have no potential conflict of interest regarding submission and publication of this manuscript.

Open Access This article is distributed under the terms of the Creative Commons Attribution License which permits any use, distribution, and reproduction in any medium, provided the original author(s) and the source are credited.

\section{References}

Adlercreutz H (2002) Phyto-oestrogens and cancer. Lancet Oncol 3:32-40

Agullo G, Gamet-Payrastre L, Manenti S, Viala C, Rémésy C, Chap H, Payrastre B (1997) Relationship between flavonoid structure and inhibition of phosphatidylinositol-3 kinase: a comparison with tyrosine kinase and protein kinase $\mathrm{C}$ inhibition. Biochem Pharmacol 53(11):1649-1657

Ahmad N, Mukhtar H (2004) Cytochrome P450: a target for drug development for skin diseases. J Investig Dermatol 123:417-425

Ahn SC, Kim GY, Kim JH, Baik SW, Han MK, Lee HJ, Moon DO, Lee CM, Kang JH, Kim BH, Oh YH, Park YM (2004) Epigallocatechin-3-gallate, constituent of green tea, suppresses the LPS-induced phenotypic and functional maturation of murine dendritic cells though inhibition of mitogen-activated-protein kinases and NF-kB. Biochem Biophys Res Commun 313: $148-155$

Akiyama T, Ishida J, Nakagawa S, Ogawara $\mathrm{H}$, Watanabe $\mathrm{S}$, Itoh $\mathrm{N}$, Shibuya M, Fukami Y (1987) Genistein, a specific inhibitor of tyrosine specific protein kinase. J Biol Chem 262:5592-5595

Alvarez AI, Real R, Perez M, Mendoza G, Prieto JG, Merino G (2010) Modulation of the activity of $\mathrm{ABC}$ transporters (P-glycoprotein, MRP2, BCRP) by flavonoids and drug response. J Pharm Sci 99:598-617

Amin AR, Thakur VS, Paul RK, Feng GS, Qu CK, Mukhtar H, Agarwal ML (2007) SHP-2 tyrosine phosphatase inhibits p73dependent apoptosis and expression of a subset of p53 target genes induced by EGCG. Proc Natl Acad Sci USA 104:54195424

Amin AR, Kucuk O, Khuri FR, Shin DM (2009) Perspectives for cancer prevention with dietary compounds. J Clin Oncol 27(16):2712-2725

Anzenbacher P, Anzenbacherová E (2011) Cytochromes P450 and metabolism of xenobiotics. Cell Mol Life Sci 58(5-6):737-747

Arai Y, Watanabe S, Kimira M, Shimoi K, Mochizuki R, Kinae N (2000) Dietary intakes of flavonols, flavones and isoflavones by Japanese women and the inverse correlation between quercetin intake and plasma LDL cholesterol concentration. J Nutr 130(9): 2243-2250

Arnold RS, He J, Remo A, Ritsick D, Yin-Goen Q, Lambeth JD, Datta MW, Young AN, Petros JA (2007) Nox1 expression determines cellular reactive oxygen and modulates c-fos induced 
growth factor, interleukin-8, and Cav-1. Am J Pathol 171(6): 2021-2032

Arts ICW (2008) A review of the epidemiological evidence on tea, flavonoids, and lung cancer. J Nutr 138:1561S-1566S

Arts IC, Hollman PC (2005) Polyphenols and disease risk in epidemiologic studies. Am J Clin Nutr 81:317S-325S

Arts IC, Jacobs DR, Gross M, Harnack LJ, Folsom AR (2002) Dietary catechins and cancer incidence among postmenopausal women: the Iowa Women's Health Study (United States). Cancer Causes Control 13:373-382

Atkinson C, Warren RML, Sala E, Dowsett M, Dunning AM, Healey CS, Runswick S, Day NE, Bingham SA (2004) Red cloverderived isoflavones and mammographic breast density: a doubleblind, randomized, placebo-controlled trial. Breast Cancer Res 6:R170-R179

Atmani D, Chaher N, Atmani D, Berboucha M, Debbache N, Boudaoud H (2009) Flavonoids in human health: from structure to biological activity. Curr Nutr Food Sci 5:225-237

Bagli E, Stefaniotou M, Morbidelli L, Ziche M, Psillas K, Murphy C, Fotsis T (2004) Luteolin inhibits vascular endothelial growth factor-induced angiogenesis; inhibition of endothelial cell survival and proliferation by targeting phosphatidylinositol 3'-kinase activity. Cancer Res 64:7936-7946

Balasuriya BWN, Rupasinghe HPV (2011) Plant flavonoids as angiotensin converting enzyme inhibitors in regulation of hypertension. Funct Foods Health Dis 5:172-188

Barkhem T, Carlsson B, Nilsson Y, Enmark E, Gustafsson JA, Nilsson S (1998) Differential response of estrogen receptor $\alpha$ and estrogen receptor $\beta$ to partial estrogen agonists/antagonists. Mol Pharmacol 54:105-112

Barnes S (1998) Phytoestrogens and breast cancer. Ballieres Clin Endocrinol Metab 12:559-579

Bazzano LA, He J, Ogden LG, Loria CM, Vupputuri S, Myers L, Whelton PK (2002) Fruit and vegetable intake and risk of cardiovascular disease in US adults: the first National Health and Nutrition Examination Survey Epidemiologic Follow-up Study. A J Clin Nutr 76(1):93-99

Bazzoli DL, Hill S, DiSilvestro RA (2002) Soy protein antioxidant actions in active, young adult women. Nutr Res 22:807-815

Birt DF, Hendrich S, Wang W (2001) Dietary agents in cancer prevention: flavonoids and isoflavonoids. Pharmacol Ther 90:157-177

Blagosklonny MV (2001) Treatment with inhibitors of caspases, that are substrates of drug transporters, selectively permits chemotherapy-induced apoptosis in multidrug-resistant cells but protects normal cells. Leukemia 15:936-941

Bobe G (2008) Flavonoid intake and risk of pancreatic cancer in male smokers (Finland). Cancer Epidemiol Biomarkers Prev 17:553-562

Boccardo F, Lunardi G, Guglielmini P, Parodi M, Murialdo R, Schettini G, Rubagotti A (2004) Serum enterolactone levels and the risk of breast cancer in women with palpable cysts. Eur J Cancer 40(1):84-89

Bode AM, Dong Z (2004) Post-translational modification of p53 in tumorigenesis. Nat Rev Cancer 4:793-805

Bosetti C, Rossi M, McLaughlin JK, Negri E, Talamini R, Lagiou P, Montella M, Ramazzotti V, Franceshi S, LaVecchia C (2007) Flavonoids and the risk of renal cell carcinoma. Cancer Epidemiol Biomarkers Prev 16(1):98-101

Brand W, Schutte ME, Williamson G, van Zanden JJ, Cnubben NH, Groten JP, van Bladeren PJ, Rietjens IM (2006) Flavonoidmediated inhibition of intestinal $\mathrm{ABC}$ transporters may affect the oral bioavailability of drugs, food-borne toxic compounds and bioactive ingredients. Biomed Pharmacother 60:508-519

Bridges AJ (2001) Chemical inhibitors of protein kinases. Chem Rev $101: 2541-2572$
Brown AK, Papaemmanouil A, Bhowruth V, Bhatt A, Dover LG, Besra GS (2007) Flavonoid inhibitors as novel antimycobacterial agents targeting Rv0636, a putative dehydratase enzyme involved in Mycobacterium tuberculosis fatty acid synthase II. Microbiology 153:3314-3322

Brueggemeier RW, Gu X, Mobley JA, Joomprabutra S, Bhat AS, Whetstone JL (2001) Effects of phytoestrogens and synthetic combinatorial libraries on aromatase, estrogen biosynthesis, and metabolism. Ann N Y Acad Sci 948:51-66

Caltagirone S, Rossi C, Poggi A, Ranalletti FO, Natali PG, Brunetti M, Aiello FB, Piantelli M (2000) Flavonoids apigenin and quercetin inhibit melanoma growth and metastatic potential. Int $\mathrm{J}$ Cancer 87:595-600

Carr AM (2000) Cell cycle: piecing together the p53 puzzle. Science 287:1765-1766

Casagrande F, Darbon JM (2001) Effects of structurally related flavonoids on cell cycle progression of human melanoma cells: regulation of cyclin-dependent kinases CDK2 and CDK1. Biochem Pharmacol 61:1205-1215

Cermak R (2008) Effect of dietary flavonoids on pathways involved in drug metabolism. Expert Opin Drug Metab Toxicol 4:17-35

Cermak R, Landgraf S, Wolffram S (2004) Quercetin glucosides inhibit glucose uptake into brush-border-membrane vesicles of porcine jejunum. Br J Nutr 91:849-855

Chahar MK, Sharma N, Dobhal MP, Joshi YC (2011) Flavonoids: a versatile source of anticancer drugs. Phcog Rev 5:1-12

Chiu FL, Lin JK (2008) Downregulation of androgen receptor expression by luteolin causes inhibition of cell proliferation and induction of apoptosis in human prostate cancer cells and xenografts. Prostate 68:61-71

Ciolino HP, Daschner PJ, Yeh GC (1999) Dietary flavonoids quercetin and kaempferol are ligands of aryl hydrocarbon receptor that affect CYP1A1 differentially. Biochem J 340:715-722

Clifford MN (2004) Diet-derived phenols in plasma and tissues and their implications for health. Planta Med 12:1103-1114

Clifford MN, Brown JE (2006) Dietary flavonoids and healthbroadening the perspective. In: Andersen $\varnothing \mathrm{M}$, Markham KR (eds) Flavonoids: chemistry, biochemistry and application, pp 319-370

Conseil G, Baubichon-Cortay H, Dayan G, Jault JM, Barron D (1998) Flavonoids: a class of modulators with bifunctional interactions at ATP- and steroid-binding sites on mouse P-glycoprotein. Proc Natl Acad Sci USA 95:9831-9836

Cotroneo MS, Wang J, Fritz WA, Eltoum IE, Lamartiniere CA (2002) Genistein action in the prepubertal mammary gland in a chemoprevention model. Carcinogenesis 23:1467-1474

D'Alessandro T, Prasain J, Botting NP, Moore R, Darley-Usmar VM, Patel RP, Barnes S (2003) Polyphenols, inflammatory response, and cancer prevention: chlorination of isoflavones by human neutrophils. J Nutr 133:3773S-3777S

Dai Q, Franke AA, Jin F, Shu XO, Hebert JR, Custer LJ, Cheng J, Gao YT, Zheng W (2002) Urinary excretion of phytoestrogens and risk of breast cancer among Chinese women in Shanghai. Cancer Epidemiol Biomarkers Prev 11:815-821

Dalu A, Haskell JF, Coward L, Lamartiniere CA (1998) Genistein, a component of soy, inhibits the expression of the EGF and ErbB/ Neu receptors in the rat dorsolateral prostate. Prostate 37:36-43

Dangles O, Dufour C (2005) Flavonoids-protein interactions. In: Andersen ØM, Markham KR (eds) Flavonoids chemistry, biochemistry and applications. CRC Press, pp 443-469

Das DK (1994) Naturally occurring flavonoids: structure, chemistry, and high performance liquid chromatography methods for separation and characterization. Methods Enzymol 234:410-420

De Santi C, Pietrabissa A, Mosca F, Rane A, Pacifici GM (2002) Inhibition of phenol sulfotransferase (SULT1A1) by quercetin in human adult and foetal livers. Xenobiotica 32:363-368 
den Tonkelaar I, Keinan-Boker L, Veer PV, Arts CJ, Adlercreutz H, Thijssen JH, Peeters PH (2001) Urinary phytoestrogens and postmenopausal breast cancer risk. Cancer Epidemiol Biomarkers Prev 10(3):223-228

Dhar DN (1994) The chemistry of chalcones and related compounds. Wiley, New York

DiPietro A, Conseil G, Perez-Victoria JM, Dayan G, BaubichonCortaya H, Trompiera D, Steinfels E, Jault JM, de Wet H, Maitrejan M, Comte G, Boumendjel A, Mariotte AM, Dumontet C, McIntosh DB, Goffeau A, Castanys S, Gamarro F, Barron D (2002) Modulation by flavonoids of cell multidrug resistance mediated by P-glycoprotein and related ABC transporters. Cell Mol Life Sci 59:307-322

Djuric Z, Chen G, Doerge DR, Heilbrun LK, Kucuk O (2001) Effect of soy isoflavone supplementation on markers of oxidative stress in men and women. Cancer Lett 172:1-6

Doostdar H, Burke MD, Mayer RT (2000) Bioflavonoids: selective substrates and inhibitors for cytochromes P450 CYP1A and CYP1B1. Toxicology 144:31-38

Fang SC, Hsu CL, Lin HT, Yen GC (2010) Anticancer effects of flavonoid derivatives isolated from Millettia reticulata Benth in SK-Hep-1 human hepatocellular carcinoma cells. J Agric Food Chem 58(2):814-820

Favot L, Martin S, Keravis T, Andriantsitohaina R, Lugnier C (2003) Involvement of cyclin-dependent pathway in the inhibitory effect of delphinidin on angiogenesis. Cardiovasc Res 59:479-487

Ferguson PJ, Kurowska E, Freeman DJ, Chambers AF, Koropatnic DJ (2004) A flavonoid fraction from cranberrry extract inhibits proliferation of human tumor cell lines. J Nutr 134(6):1529-1535

Ferreira JFS, Luthria DL, Sasaki T, Heyerick A (2010) Flavonoids from Artemisia апnиa L. as antioxidants and their potential synergism with artimisin against malaria and cancer. Molecules $15: 3135-3170$

Firestone GL, Sundar SN (2009) Anticancer activities of artemisinin and its bioactive derivatives. Expert Rev Mol Med 11:1-15

Foti P, Erba D, Riso P, Spadafranca A, Criscuoli F, Testolin G (2005) Comparison between daidzein and genistein antioxidant activity in primary and cancer lymphocytes. Arch Biochem Biophys 433:427-431

Fotsis T, Pepper M, Adlercreutz H, Fleischmann G, Hase T, Montesano R, Schweigerer L (1993) Genistein, a dietary-derived inhibitor of in vitro angiogenesis. Proc Natl Acad Sci USA 90:2690-2694

Fotsis T, Pepper M, Adlercreutz H, Hase T, Montesano R, Schweigerer L (1995) Genistein, a dietary ingested isoflavonoid, inhibits cell proliferation and in vitro angiogenesis. J Nutr 125:790S-797S

Fotsis T, Pepper MS, Aktas E, Breit S, Rasku S, Adlercreutz H, Wähälä K, Montesano R, Schweigerer L (1997) Flavonoids, dietary-derived inhibitors of cell proliferation and in vitro angiogenesis. Cancer Res 57:2916-2921

Franco OH, Bonneux L, de Laet C, Peeters A, Steyerberg EW, Mackenbach JP (2004) The Polymeal: a more natural, safer, and probably tastier (than the Polypill) strategy to reduce cardiovascular disease by more than 75\%. BMJ 329:1447-1450

Fukuyama M, Rokutan K, Sano T, Miyake H, Shimada M, Tashiro S (2005) Overexpression of a novel superoxide producing enzyme, NADPH oxidase 1, in adenoma and well differentiated adenocarcinoma of the human colon. Cancer Lett 221(1):97-104

Galijatovic A, Otake Y, Walle UK, Walle T (2001) Induction of UDP-glucuronosyltransferase UGT1A1 by the flavonoid chrysin in Caco-2 cells: potential role in carcinogen bioinactivation. Pharm Res 18:374-379

Gamet-Payrastre L, Manenti S, Gratacap MP, Tulliez J, Chap H, Payrastre B (1999) Flavonoids and the inhibition of PKC and PI 3-kinase. Gen Pharmacol 32:279-286
Garcia-Closas R, Gonzalez CA, Agudo A, Riboli E (1999) Intake of specific carotenoids and flavonoids and the risk of gastric cancer in Spain. Cancer Causes Control 10:71-75

Gibellini L, Pinti M, Nasi M, Montagna JP, De Biasi S, Roat E, Bertoncelli L, Cooper EL, Cossarizza A (2011) Quercetin and cancer chemoprevention. Evid Based Complement Alternat Med 2011:591356

Giuliani C, Noguchi Y, Harii N, Napolitano G, Tatone D, Bucci I, Piantelli M, Monaco F, Kohn LD (2008) The flavonoid quercetin regulates growth and gene expression in rat FRTL-5 thyroid cells. Endocrinology 149(1):84-92

Goetzl MA, VanVeldhuizen PJ, Thrasher JB (2007) Effect of soy phytoestrogens on the prostate. Prostate Cancer Prostatic Dis 10:216-223

Gould KS, Lister C (2005) Flavonoid functions in plants. In: Andersen OM, Markham KR (eds) Flavonoids chemistry, biochemistry and applications. CRC Press Taylor \& Francis Group, London, pp 397-442

Griffiths LA, Barrow A (1972) The fate of orally and parenterally administered flavonoids in the mammal. The significance of biliary excretion. Angiologica 9:30-42

Guo JY, Li X, Browning JD Jr, Rottinghaus GE, Lubahn DB, Constantinou A, Bennink M, MacDonald RS (2004) Dietary soy isoflavones and estrone protect ovariectomized ERalphaKO and wild-type mice from carcinogen-induced colon cancer. J Nutr 134:179-182

Hackett AM (1986) The metabolism of flavonoid compounds in mammals. In: Cody V, Middleton E Jr, Harborne JB (eds) Plant flavonoids in biology and medicine: biochemical, pharmacological, and structure-activity relationships. Alan R Liss lnc, New York, pp 177-194

Haddad AQ (2008) The cellular and molecular properties of flavonoids in prostate cancer chemoprevention. Ph.D Thesis, Institute of Medical Science, University of Toronto

Harborne JB (ed) (1994) The flavonoids: advances in research since 1986. Chapman \& Hall, London

Harborne JB, Williams CA (2000) Advances in flavonoid research since 1992. Phytochemistry 55(6):481-504

Haslam E (1996) Natural polyphenols (vegetable tannins) as drugs: possible modes of action. J Nat Prod 59:205-215

Hassan S, Mathesius U (2012) The role of flavonoids in rootrhizosphere signalling: opportunities and challenges for improving plant-microbe interactions. J Exp Bot 63(9):3429-3444

Hastak K, Gupta S, Ahmad N, Agarwal MK, Agarwal ML, Mukhtar H (2003) Role of p53 and NF-kappaB in epigallocatechin-3gallateinduced apoptosis of LNCaP cells. Oncogene 22:4851-4859

Havsteen BH (2002) The biochemistry and medical significance of flavonoids. Pharmacol Ther 96:67-202

He L, Wu Y, Lin L, Wang J, Wu Y, Chen Y, Yi Z, Liu M, Pang X (2011) Hispidulin, a small flavonoid molecule, suppresses the angiogenesis and growth of human pancreatic cancer by targeting vascular endothelial growth factor receptor 2-mediated $\mathrm{PI} 3 \mathrm{~K} / \mathrm{Akt} / \mathrm{mTOR}$ signaling pathway. Cancer Sci 102(1):219-225

Heinonen M, Rein D, Teresa Satué-Gracia M, Huang S-W, BruceGerman J, Frankel EN (1998) Effect of protein on the antioxidant activity of phenolic compounds in a lecithinliposome oxidation system. J Agric Food Chem 46:917-922

Heller W, Forkmann G (1993) Biosynthesis. In: Harborne JB (ed) The flavonoids. Advances in research since 1986. Chapman and Hall Ltd, London, pp 499-535

Hertog MGL, Hollman PCH, Katan MB (1992) Content of potentially anticinogenic flavonoids of 28 vegetables and 9 fruits commonly consumed in the Netherlands. J Agric Food Chem 40:2379-2383

Hertog MGL, Hollman PCH, van de Putte B (1993a) Content of potentially anticarcinogenic flavonoids of tea infusions, wines, and fruit juices. J Agric Food Chem 41:1242-1246 
Hertog MGL, Hollman PCH, Katan MB, Kromhout D (1993b) Intake of potentially anticarcinogenic flavonoids and their determinants in adults in the Netherlands. Nutr Cancer 20:21-29

Ho JS, Ma W, Mao DY, Benchimol S (2005) p53-dependent transcriptional repression of c-myc is required for $\mathrm{G} 1$ cell cycle arrest. Mol Cell Biol 25:7423-7431

Hodek P, Trefil P, Stiborova M (2002) Flavonoids: potent and versatile biologically active compounds interacting with cytochromes P450. Chem Biol Interact 139(1):1-21

Hodek P, Tepla M, Krizkova J, Sulc M, Stiborova M (2009) Modulation of cytochrome P450 enzyme system by selected flavonoids. Neuro Endocrinol Lett 30(1):67-71

Holland B, Welch AA, Unwin ID, Buss DH, Paul AA, Southgate DAT (1995) McCance and Widdowson's the composition of foods, 5th edn. Royal Society of Chemistry, Cambridge

Hollman PCH (2004) Absorption, bioavailability, and metabolism of flavonoids. Pharm Biol 42(S):74-83

Hollman PCH, Katan MB (1998) Absorption, metabolism, and bioavailability of flavonoids. In: Rice-Evans CA, Paker L (eds) Flavonoids in health and disease. Marcel Dekker Inc, New York, pp 483-522

Hollman PCH, Katan MB (1999) Dietary flavonoids: intake, health effects and bioavailability. Food Chem Toxicol 37:937

Holzbeierlein JM, McIntosh J, Thrasher JB (2005) The role of soy phytoestrogens in prostate cancer. Curr Opin Urol 15:17-22

Ingram D, Sanders K, Kolybaba M, Lopez D (1997) Case control study of phyto-oestrogens and breast cancer. Lancet 350:990-994

Johnson IT (2004) New approaches to the role of diet in the prevention of cancers of the alimentary tract. Mutat Res 551(1-2):9-28

Johnson DW, Berg JN, Baldwin MA et al (1996) Mutations in the activin receptor-like kinase I gene in hereditary haemorrhagic telangiectasia type 2. Nat Genet 13:189-195

Johnson J, Maher P, Hanneken A (2009) The flavonoid, eriodictyol, induces long-term protection in ARPE-19 cells through its effects on Nrf2 activation and phase II gene expression. Invest Ophthalmol Vis Sci 50(5):2398-2406

Joussen AM, Rohrschneider K, Reichling J, Kirchhof B, Kruse FE (2000) Treatment of corneal neovascularization with dietary isoflavonoids and flavonoids. Exp Eye Res 71(5):483-487

Ju W, Wang X, Shi H, Chen W, Belinsky SA, Lin Y (2007) A critical role of luteolin-induced reactive oxygen species in blockage of tumor necrosis factor-activated nuclear factor kappa B pathway and sensitization of apoptosis in lung cancer cells. Mol Pharmacol 71:1381-1388

Kameshwaran S, Suresh V, Arunachalam G, Kanthlal SK, Mohanraj M (2012) In vitro and in vivo anticancer activity of methanolic flower extract of Tecoma stans flower. Int Res J Pharm 3(3): 246-252

Kang ZC, Tsai SJ, Lee H (1999) Quercetin inhibits benzo[a]pyreneinduced DNA adducts in human Hep G2 cells by altering cytochrome P-450 1A1 expression. Nutr Cancer 35:175-179

Kilkkinen A, Virtamo J, Vartiainen E, Sankila R, Virtanen MJ, Adlercreutz H, Pietinen P (2004) Serum enterolactone concentration is not associated with breast cancer risk in a nested casecontrol study. Int J Cancer 108(2):277-280

Kim MH (2003) Flavonoids inhibit VEGF/bFGF-induced angiogenesis in vitro by inhibiting the matrix-degrading proteases. J Cell Biochem 89(3):529-538

Kim H, Peterson TG, Barnes S (1998) Mechanisms of action of the soy isoflavone genistein: emerging role of its effects through transforming growth factor beta signaling pathways. Am J Clin Nutr 68:1418S-1425S

Kim YJ et al (2004) Superoxide anion scavenging and xanthine oxidase inhibition of (p)-catechin-aldehyde polycondensates. Amplification of the antioxidant property of (p)-catechin by polycondensation with aldehydes. Biomacromolecules 5:547
Kim JH, Kang JW, Kim MS, Bak Y, Park YS, Jung KY, Lim YH, Yoon DY (2012) The apoptotic effects of the flavonoid N101-2 in human cervical cancer cells. Toxicol In Vitro 26(1):67-73

Kioka M, Hosokawa N, Komano T, Hirayoshi K, Nagata K, Ueda K (1992) Quercetin, a bioflavonoid, inhibits the increase of human multidrug resistance gene (MDR1) expression caused by arsenite. FEBS Lett 301:307-309

Knekt P, Jarvinen R, Reunanen A, Maatela J (1996) Flavonoid intake and coronary mortality in Finland: a cohort study. Br Med J 312:478-481

Knekt P, Kumpulainen J, Jarvinen R, Rissanen H, Heliovaara M, Reunanen A, Hakulinen T, Aromaa A (2002) Flavonoid intake and risk of chronic diseases. Am J Clin Nutr 76:560-568

Kroon PA, Clifford MN, Crozier A, Day AJ, Donovan JL, Manach C, Williamson G (2004) How should we assess the effects of exposure to dietary polyphenols in vitro? Am J Clin Nutr $80: 15-21$

Kruse FE, Joussen AM, Fotsis $\mathrm{T}$ et al (1997) Inhibition of neovacularization of the eye by dietary factors exemplified by isoflavonoids. Ophthalmologie 94:152-156

Kuiper GGJM, Carlsson B, Grandien K, Enmark E, Haggblad J, Nilsson S, Gustafsson JA (1997) Comparison of the ligand binding specificity and transcript tissue distribution of estrogen receptors a and b. Endocrinology 138:863-870

Kuiper GGJM, Lemmen JG, Carlsson BO, Corton JC, Safe SH, van der Saag PT, van der Burg B, Gustafsson JA (1998) Interaction of estrogenic chemicals and phytoestrogens with estrogen receptor b. Endocrinology 139:4252-4263

Kumar PS, Sucheta S, Deepa VS, Selavamani P, Latha S (2008) Antioxidant activity in some selected Indian medicinal plants. African J Biotechnol 7(12):1826-1828

Kurisawa M, Chung JE, Kim YJ, Uyama H, Kobayashi S (2003) Amplification of antioxidant activity and xanthine oxidase inhibition of catechin by enzymatic polymerization. Biomacromolecules 4:469-471

Lagiou P, Rossi M, Lagiou A, Tzonou A, La Vecchia C, Trichopoulos D (2008) Flavonoid intake and liver cancer: a case-control study in Greece. Cancer Causes Control 19(8):813-818

Lai H, Sasaki T, Singh NP, Messay A (2005) Effects of artemisinintagged holotrasferrin on cancer cells. Life Sci 76:1267-1279

Lakshman M, Xu L, Ananthanarayanan V, Cooper J, Takimoto CH, Helenowski I, Pelling JC, Bergan RC (2008) Dietary genistein inhibits metastasis of human prostate cancer in mice. Cancer Res 68:2024-2032

Le Bail JC, Laroche T, Marre-Fournier F, Habrioux G (1998) Aromatase and $17 \beta$-hydroxysteroid dehydrogenase inhibition by flavonoids. Cancer Lett 133:101-110

Le Marchand L, Murphy SP, Hankin JH, Wilkens LR, Kolonel LN (2000) Intake of flavonoids and lung cancer. J Natl Cancer Inst 92:154-160

Li YC (2011) Antioxidant activity of flavonoids from sweet potato vines in vitro. Adv Mater Res 236-238:2634-2638

Li Y, Kucuk O, Hussain M, Abrams J, Cher ML, Sarkar FH (2006) Antitumor and antimetastatic activities of docetaxel are enhanced by genistein through regulation of osteoprotegerin/ receptor activator of nuclear factor-B (RANK)/RANK ligand/ MMP-9 signaling in prostate cancer. Cancer Res 66:4816-4825

Li J, Cheng Y, Qu W, Sun Y, Wang Z, Wang H, Tian B (2011a) Fisetin, a dietary flavonoid, induces cell cycle arrest and apoptosis through activation of p53 and inhibition of NF-kappa $\mathrm{B}$ pathways in bladder cancer cells. Basic Clin Pharmacol Toxicol 108(2):84-93

Li X, Wang JN, Huang JM, Xiong XK, Chen MF, Ong CN, Shen HM, Yang XF (2011b) Chrysin promotes tumor necrosis factor (TNF)-related apoptosis-inducing ligand (TRAIL) induced apoptosis in human cancer cell lines. Toxicol In Vitro 25(3):630-635 
Lim SD, Sun C, Lambeth JD, Marshall F, Amin M, Chung L, Petros JA, Arnold RS (2005) Increased Nox 1 and hydrogen peroxide in prostate cancer. Prostate 62(2):200-207

Liu SL, Lin X, Shi DY, Cheng J, Wu C, Zhang YD (2002) Reactive oxygen species stimulated human hepatoma cell proliferation via cross-talk between PI3-K/PKB and JNK signaling pathways. Arch Biochem Biophys 406:173-182

Liu G, Ding L, Luo C, Yang H, Yang D, Liang G, Wang L (2006) Protection against DNA damage and inhibition of lipid peroxidation by flavones from Eremosparton songoricum (Litv) Vass. Res Chem Intermed 32(2):145-152

Liu EH, Qi LW, Li P (2010) Structural relationship and binding mechanisms of five flavonoids with bovine serum albumin. Molecules 15:9092-9103

Liu PX, Gao J, Chen YJ, Long W, Shen X, Tang WS (2011) Anticancer activity of total flavonoids isolated from Xianhe Yanling Recipe. Chin J Integr Med 17(6):459-463

Lund TD, Munson DJ, Haldy ME, Setchell KDR, Lephart ED, Handa RJ (2004) Equol is a novel anti-androgen that inhibits prostate growth and hormone feedback. Biol Reprod 70:1188-1195

Luo H, Daddysman MK, Rankin GO, Jiang BH, Chen YC (2010) Kaempferol enhances cisplatin's effect on ovarian cancer cells through promoting apoptosis caused by down regulation of cMyc. Cancer Cell Int 10:16

Manach C, Morand C, Demigne C, Texier O, Regerat F, Remesy C (1997) Bioavailability of rutin and quercetin in rats. FEBS Lett 409:12-16

Marchetti F, De Santi C, Vietri M, Pietrabissa A, Spisni R, Mosca F, Pacifici GM (2001) Differential inhibition of human liver and duodenum sulphotransferase activities by quercetin, a flavonoid present in vegetables, fruit and wine. Xenobiotica 31:841-847

McCann SE, Moysich KB, Freudenheim JL, Ambrosone CB, Shields PG (2002) The risk of breast cancer associated with dietary lignans differs by CYP17 genotype in women. J Nutr 132(10):3036-3041

McCann SE, Muti P, Vito D, Edge SB, Trevisan M, Freudenheim JL (2004) Dietary lignan intakes and risk of pre- and postmenopausal breast cancer. Int J Cancer 111(3):440-443

McRae JM, Kennedy JA (2011) Wine and grape tannin interactions with salivary proteins and their impact on astringency: a review of current research. Molecules 16:2348-2364

Meng X, Lee MJ, Li C, Sheng S, Zhu N, Sang S, Ho CT, Yang CS (2001) Formation and identification of $4^{\prime}$-O-methyl-(-)-epigallocatechin in humans. Drug Metab Dispos 29:789-793

Messina MJ, Persky V, Setchell KDR, Barnes S (1994) Soy intake and cancer risk; a review of the in vitro and in vivo data. Nutr Cancer 21:114-131

Middleton E, Kandaswami C (1994) The impact of plant flavonoids on mammalian biology: implications for immunity, inflammation and cancer. In: Harborne JB (ed) The flavonoids, advances in research since 1986. Chapman \& Hall, London, pp 619-645

Mitchell JH, Gardner PT, Mcphail DB, Morrice PC, Collins AR, Duthie GG (1998) Antioxidant efficacy of phytoestrogens in chemical and biological model systems. Arch Biochem Biophys 360:142-148

Modak B, Torres R, Urzúa A (2011) Seasonal variation of the flavonoids pinocembrin and 3-O-methylgalangin, in the surface component mixture (resinous exudates and waxy coating) of Heliotropium stenophyllum. J Chil Chem Soc 56(1):532-534

Molepo RS (2010) Flavonoid induction of cytochrome P450 (CYP) in human esophageal carcinoma cells: implications for chemotherapy. M. Sc Thesis, University of the Witwatersrand, Johannesberg

Monasterio A, Urdaci MC, Pinchuk IV et al. (2004) Flavonoids induce apoptosis in human leukemia U937 cells through caspaseand caspase-calpaindependent pathways. Nutr cancer 50:90-100
Moon YJ, Wang X, Morris ME (2006) Dietary flavonoids: effects on xenobiotic and carcinogen metabolism. Toxicol In Vitro 20(2): $187-210$

Morris ME, Zhang S (2006) Flavonoid-drug interactions: effects of flavonoids on ABC transporters. Life Sci 78:2116-2130

Mueller SO, Simon S, Chae K, Metzler M, Korach KS (2004) Phytoestrogens and their human metabolites show distinct agonistic and antagonistic properties on estrogen receptor (alpha) and ER(beta) in human cells. Toxicol Sci 81:530-531

Nakase I, Gallis B, Takatani-Nakase T, Oh S, Lacoste E, Singh NP, Goodlett DR, Tanaka S, Futaki S, Lai H, Sasaki T (2009) Transferrin receptor-dependent cytotoxicity of artemisinintransferrin conjugates on prostate cancer cells and induction of apoptosis. Cancer Lett 274:290-298

Nardini M, Cirillo E, Natella F, Scaccini C (2002) Absorption of phenolic acids in humans after coffee consumption. J Agric Food Chem 50:5735-5741

Neuhouser ML (2004) Dietary flavonoids and cancer risk: evidence from human population studies. Nutr Cancer 50(1):1-7

Nijeveldt R, Nood EV, Hoorn DECV, Boelens PG, Norren KV, Leeawen PAMV (2001) Flavonoids: a review of probable mechanisms of action and potential applications. Am J Clin Nutr 74:418-425

Nothlings U, Murphy SP, Wilkens LR, Boeing H et al (2008) A food pattern that is predictive of flavonol intake and risk of pancreatic cancer. Am J Clin Nutr 88(6):1653-1662

Ofer M, Wolffram S, Koggel A, Spahn-Langguth H, Langguth P (2006) Modulation of drug transport by selected flavonoids: involvement of P-gp and OCT? Eur J Pharm Sci 25(2-3):263-271

Ogbuewu IP, Uchegbu MC, Emenalom OO, Okoli IC, Iloeje MU (2010) Overview of the chemistry of soy isoflavones, potential threats and potential therapeutic benefits. Electron $\mathrm{J}$ Environ Agric Food Chem 9(4):682-695

Oh S, Kim BJ, Singh NP, Lai H, Sasaki T (2009) Synthesis and anticancer activity of covalent conjugates of artemisinin and a transferrin-receptor targeting peptide. Cancer Lett 274:33-39

Ohta T, Nakatsugi S, Watanabe K, Kawamori T, Ishikawa F, Morotomi M, Sugie S, Toda T, Sugimura T, Wakabayashi K (2000) Inhibitory effects of bifido-bacterium-fermented soy milk on PhIP-induced rat mammary carcinogenesis, with partial contribution of its component isoflavaones. Carcinogenesis 21:937-941

Oikawa T, Shimamura M, Ashino H, Nakamura O, Kanayasu T, Morita I, Murota S (1992) Inhibition of angiogenesis by staurosporine, a potent protein kinase inhibitor. J Antibiot (Tokyo) 45:1155-1160

Okushio K, Matsumoto N, Kohri T, Suzuki M, Nanjo F, Hara Y (1996) Absorption of tea catechins into rat portal vein. Biol Pharm Bull 19:326-329

Olthof MR, Hollman PC, Vree TB, Katan MB (2000) Bioavailabilities of quercetin-3-glucoside and quercetin-4'-glucoside do not differ in humans. J Nutr 130:1200-1203

Olthof MR, Hollman PC, Buijsman MN, van Amelsvoort JM, Katan MB (2003) Chlorogenic acid, quercetin-3-rutinoside and black tea phenols are extensively metabolized in humans. J Nutr 133:1806-1814

Ørgaard A, Jensen L (2008) The effects of soy isoflavones on obesity. Exp Biol Med 233(9):1066-1080

Oršolić N, Benković V, Lisičić D, Đikić D, Erhardt J, Knežević AH (2010) Protective effects of propolis and related polyphenolic/ flavonoid compounds against toxicity induced by irinotecan. Med Oncol 27(4):1346-1358

Parr AJ, Bolwell GP (2000) Phenols in the plant and in man. The potential for possible nutritional enhancement of the diet by modifying phenolic content or composition. J Sci Food Agric 80:985-1012 
Pascual-Teresa D, Santos-Buelga S, Rivas-Gonzalo JC (2000) Quantitative analysis of flavan-3-ols in Spanish foodstuffs and beverages. J Agric Food Chem 48:5331-5337

Passamonti S, Terdoslavich M, Franca R, Vanzo A, Tramer F, Braidot E, Petrussa E, Vianello A (2009) Bioavailability of flavonoids: a review of their membrane transport and the function of bilitranslocase in animal and plant organisms. Curr Drug Metab 10:369-394

Patel MJ (2008) A review of potential health benefits of flavonoids. Lethbridge Undergrad Res J 3(2)

Peng W, Kuo SM (2003) Flavonoid structure affects the inhibition of lipid peroxidation in caco-2 intestinal cells at physiological concentrations. J Nutr 133(7):2184-2187

Peng Y, Li QW, Jian L (2011) Antitumor activity of Scutellaria baicalensis Georgi total flavonoids on mice bearing U14 cervical carcinoma. Afr J Biotechnol 10(82):19167-19175

Perez JL, Jayaprakasha GK, Cadena A, Martinez E, Hassan A, Patil BS (2010) In vivo induction of phase II detoxifying enzymes, glutathione transferase and quinone reductase by citrus triterpenoids. BMC Complement Altern Med 10:51

Perez-Victoria JM, Chiquero MJ, Conseil G, Dayan G, Di Pietro A, Barron D, Castanys S, Gamarro F (1999) Correlation between the affinity of flavonoids binding to the cytosolic site of Leishmania tropica multidrug transporter and their efficiency to revert parasite resistance to daunomycin. Biochemistry 38:1736-1743

Perez-Vizcaino F, Duarte J, Jimenez R, Santos-Buelga C, Osuna A (2009) Antihypertensive effects of the flavonoid quercetin. Pharmacol Rep 61(1):67-75

Peterson J, Lagiou P, Samoli E, Lagiou A, Katsouyanni K et al (2003) Flavonoid intake and breast cancer risk: a case control study in Greece. Br J Cancer 89(7):1255-1259

Petri N, Tannergren C, Holst B, Mellon FA, Bao Y, Plumb GW, Bacon J, O'Leary KA, Kroon PA, Knutson L, Forsell P, Eriksson T, Lennernas H, Williamson G (2003) Absorption/metabolism of sulforaphane and quercetin, and regulation of phase II enzymes, in human jejunum in vivo. Drug Metab Dispos 31:805-813

Phan TA, Yu XM, Kunnimalaiyaan M, Chen H (2011) Antiproliferative effect of chrysin on anaplastic thyroid cancer. J Surg Res 170(1):84-88

Pietinen P, Stumpf K, Männistö S, Kataja V, Uusitupa M, Adlercreutz H (2001) Serum enterolactone and risk of breast cancer: a casecontrol study in Eastern Finland. Cancer Epidemiol Biomarkers Prev 10:33

Pike ACW, Brzozowski AM, Hubbard RE, Bonn T, Thorsell AG, Engstrom O, Ljunggren J, Gustafsson JÅ, Carlquist M (1999) Structure of the ligand-binding domain of oestrogen receptor beta in the presence of a partial agonist and a full antagonist. EMBO J 18:4608-4618

Poli G, Leonarduzzi G, Biasi F, Chiarpotto E (2004) Oxidative stress and cell signalling. Curr Med Chem 11(9):1163-1182

Qin Y, Li Z, Chen Y, Hui H, Sun Y, Yang H, Lu Na, Guo Q (2012) III-10, a newly synthesized flavonoid, induced differentiation of human U937 leukemia cells via PKC $\delta$ activation. Eur J Pharm Sci 45(5):648-656

Rahman S, Salehin F, Iqbal A (2011) In vitro antioxidant and anticancer activity of young Zingiber officinale against human breast carcinoma cell lines. BMC Complement Altern Med 11:76

Ravichandiran V, Ahamed HN, Nirmala S (2011) Natural flavonoids and lung cancer. Pharmacie Globale 6(2):1-9

Renaud S, de Lorgeril M (1992) Wine, alcohol, platelets, and the French paradox for coronary heart disease. Lancet 339:1523-1526

Robards K, Antolovich M (1997) Analytical chemistry of fruit bioflavonoids. Analyst 122:11R-34R

Rodriguez-Proteau R, Mata JE, Miranda CL, Fan Y, Brown JJ, Buhler DR (2006) Plant polyphenols and multidrug resistance: effects of dietary flavonoids on drug transporters in Caco-2 and MDCKIIMDR1 cell transport models. Xenobiotica 36(1):41-58

Romanouskaya TV, Grinev VV (2009) Cytotoxic effect of flavonoids on leukemia cells and normal cells of human blood. Bull Exp Biol Med 148(1):57-59

Rossi M, Garavello W, Talamini R, Negri E, Bosetti C, Dal Maso L, Lagiou P, Tavani A, Polesel J, Barzan L, Ramazzotti V, Franceschi S, Vecchia C (2007) Flavonoids and the risk of oral and pharyngeal cancer: a case-control study from Italy. Cancer Epidemiol Biomarkers Prev 16:1621-1625

Rossi M, Bosetti C, Negri E, Lagiou P, La Vecchia C (2010) Flavonoids, proanthocyanidins, and cancer risk: a network of case-control studies from Italy. Nutr Cancer 62(7):871-877

Roy AM, Baliga MS, Katiyar SK (2005) Epigallocatechin-3-gallate induces apoptosis in estrogen receptor-negative human breast carcinoma cells via modulation in protein expression of p53 and Bax and caspase-3 activation. Mol Cancer Ther 4:81-90

Rudrabhatla P, Rajasekharan R (2005) Functional characterization of peanut serine/threonine/tyrosine protein kinase: molecular docking and inhibition kinetics with tyrosine kinase inhibitors. Biochemistry 43(38): 12123-12132

Ruela-de-Sousa RR, Fuhler GM, Blom N, Ferreira CV, Aoyama H, Peppelenbosch MP (2010) Cytotoxicity of apigenin on leukemia cell lines: implications for prevention and therapy. Cell Death Dis 1(1):19

Russo GL (2007) Ins and outs of dietary phytochemicals in cancer chemoprevention. Biochem Pharmacol 74(4):533-544

Saewan N, Koysomboon S, Chantrapromma K (2011) Anti-tyrosinase and anti-cancer activities of flavonoids from Blumea balsamifera DC. J Med Plants Res 5(6):1018-1025

Samanta A, Das G, Das SK (2011) Roles of flavonoids in plants. Int J Pharm Sci Technol 6(1):12-35

Sandhar HK, Kumar B, Prasher S, Tiwari P, Salhan M, Sharma P (2011) A review of phytochemistry and pharmacology of flavonoids. Int Pharm Sci 1:25-41

Sathyamoorthy N, Gilsdorf JS, Wang TT (2005) Differential effect of genistein on transforming growth factor beta1 expression in normal and malignant mammary epithelial cells. Anticancer Res 18(4A):2449-2453

Sato T, Koike L, Miyata Y, Hirata M, Mimaki Y, Sashida Y, Yano M, Ito A (2002) Inhibition of activator protein-1 binding activity and phosphatidylinositol-3-kinase pathway by nobelitin, a polyhydroxy flavonoid, results in augmentation of TIMP-1 production and suppression of production of matrix metalloproteinases- 1 and -9 in human fibrosarcoma HT-1080 cells. Cancer Res 62:1025-1029

Scalbert A, Williamson G (2000) Dietary intake and bioavailability of polyphenols. J Nutr 130:S2073-S2085

Scheline RR (1991) Handbook of mammalian metabolism of plant compounds. CRC Press, Boca Raton

Schindler R, Mentlein R (2006) Flavonoids and vitamin E reduce the release of the angiogenic peptide vascular endothelial growth factor from human tumor cells. J Nutr 136(6):1477-1482

Schmidt F, Knobbe CB, Frank B, Wolburg H, Weller M (2008) The topoisomerase II inhibitor, genistein, induces G2/M arrest and apoptosis in human malignant glioma cell lines. Oncol Rep 19:1061-1066

Schroeter H, Spencer JP, Rice-Evans C, Williams RJ (2001) Flavonoids protect neurons from oxidized low-density-lipoprotein-induced apoptosis involving c-Jun N-terminal kinase (JNK), c-Jun and caspase-3. Biochem J 358:547-557

Schroeter H, Boyd C, Spencer JP, Williams RJ, Cadenas E, RiceEvans C (2002) MAPK signaling in neurodegeneration: influences of flavonoids and of nitric oxide. Neurobiol Aging 23:861-880

Seelinger G, Merfort I, Wolfle U, Schempp CM (2008) Anticarcinogenic effects of the flavonoid luteolin. Molecules $13: 2628-2651$

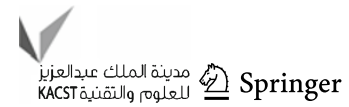


Selvendiran K, Koga H, Ueno T, Yoshida T, Maeyama M, Torimura T, Yano H, Kojiro M, Sata M (2006) Luteolin promotes degradation in signal transducer and activator of transcription 3 in human hepatoma cells: an implication for the antitumor potential of flavonoids. Cancer Res 66(9):4826-4834

Seufi AM, Ibrahim SS, Elmaghraby TK, Hafez EE (2009) Preventive effect of the flavonoid, quercetin, on hepatic cancer in rats via oxidant/antioxidant activity: molecular and histological evidences. J Exp Clin Cancer Res 28:80

Shapiro AB, Ling V (1997) Effects of quercetin on Hoechst 33342 transport by purified and reconstituted P-glycoprotein. Biochem Pharmacol 53:587-596

Shaulian E, Karin M (2002) AP-1 as a regulator of cell life and death. Nat Cell Biol 4:E131-E136

Sivoňová M, Žitňanová I, Horáková L, Štrosová M, Muchová J, Balgavý P, Dobrota D, Duračková Z (2006) The combined effect of pycnogenol with ascorbic acid and trolox on the oxidation of lipids and proteins. Gen Physiol Biophys 25:379-396

So FV, Guthrie N, Chambers AF, Carroll KK (1997) Inhibition of proliferation of estrogen receptor positive MCF-7 human breast cancer cells by flavonoids in the presence and absence of excess estrogen. Cancer Lett 112:127-133

Spencer CM et al (1988) Polyphenol complexation-some thoughts and observations. Phytochemistry 27:2397-2409

Stefani ED, Boffetta P, Deneo-Pellegrini H, Mendilaharsu M, Carzoglio JC, Ronco A, Olivera L (1999a) Dietary antioxidants and lung cancer risk: a case-control study in Uruguay. Nutr Cancer 34:100-110

Stefani ED, Ronco A, Mendilaharsu M, Deneo-Pellegrini H (1999b) Diet and risk of cancer of the upper aerodigestive tract-II. Nutr Oral Oncol 35:22-26

Stevens JF, Page JE (2004) Xanthohumol and related prenylflavonoids from hops and beer: to your good health. Phytochemistry 65:1317-1330

Su SJ, Yeh TM, Chuang WJ, Ho CL, Chang KL, Cheng HL, Liu HS, Cheng HL, Hsu PY, Chow NH (2005) The novel targets for antiangiogenesis of genistein on human cells. Biochem Pharmacol 69:307-318

Sugatani J, Yamakawa K, Tonda E, Nishitani S, Yoshinari K, Degawa M, Abe I, Noguchi H, Miwa M (2004) The induction of human UDP-glucuronosyltransferase 1A1 mediated through a distal enhancer module by flavonoids and xenobiotics. Biochem Pharmacol 67:989-1000

Tang NP, Zhou B, Wang B, Yu RB, Ma J (2009) Flavonoids intake and risk of lung cancer: a meta-analysis. Jpn J Clin Oncol 39(6):352-359

Tosetti F, Ferrari N, De Flora S, Albini A (2002) Angioprevention': angiogenesis is a common and key target for cancer chemopreventive agents. FASEB J 16(1):2-14

Tsao AS, Edward SK, Hong WK (2004) Chemoprevention of cancer. CA Cancer J Clin 54:150-180

Valko M, Izakovic M, Mazur M, Rhodes CJ, Telser J (2004) Role of oxygen radicals in DNA damage and cancer incidence. Mol Cell Biochem 266(1):37-56

van der Logt EM, Roelofs HM, Nagengast FM, Peters WH (2003) Induction of rat hepatic and intestinal UDP-glucuronosyltransferases by naturally occurring dietary anticarcinogens. Carcinogenesis 24:1651-1656

Ververidis F, Trantas E, Douglas C, Vollmer G, Kretzschmar G, Panopoulos N (2007) Biotechnology of flavonoids and other phenylpropanoid-derived natural products. Part I: chemical diversity, impacts on plant biology and human health. Biotechnol J 2(10):1214-1234

Vidya PR, Senthil MR, Maitreyi S, Ramalingam K, Karunagaran D, Nagini S (2010) The flavonoid quercetin induces cell cycle arrest and mitochondria-mediated apoptosis in human cervical cancer
(HeLa) cells through p53 induction and NF- $\kappa \mathrm{B}$ inhibition. Eur J Pharmacol 649(1-3):84-91

Vietri M, Vaglini F, Pietrabissa A, Spisni R, Mosca F, Pacifici GM (2002) Sulfation of $\mathrm{R}(-)$-apomorphine in the human liver and duodenum, and its inhibition by mefenamic acid, salicylic acid and quercetin. Xenobiotica 32:587-594

von Moltke LL, Weemhoff JL, Bedir E, Khan IA, Harmatz JS, Goldman P, Greenblatt DJ (2004) Inhibition of human cytochromes $\mathrm{P} 450$ by components of Ginkgo biloba. J Pharm Pharmacol 56:1039-1044

Wagner H, Farkas L (1975) Synthesis of flavonoids. In: Harborne JB, Mabry TJ, Mabry H (eds) The flavonoids. Part I. Academic Press, New York, pp 127-213

Walle UK, Walle T (2002) Induction of human UDP-glucuronosyltransferase UGT1A1 by flavonoids-structural requirements. Drug Metab Dispos 30:564-569

Walle T, Walle UK, Halushka PV (2001) Carbon dioxide is the major metabolite of quercetin in humans. J Nutr 131:2648-2652

Wallstrom P, Wirfalt E, Janzon L, Mattisson I, Elmstahl S, Johansson U, Berglund G (2000) Fruit and vegetable consumption in relation to risk factors for cancer: a report from the Malmo Diet and Cancer Study. Public Health Nutr 3:263-271

Wang B, Zhang X (2012) Inhibitory effects of Broccolini leaf flavonoids on human cancer cells. Scanning 34(1):1-5

Wei H, Tye L, Bresnick E, Birt DF (1990) Inhibitory effect of apigenin, a plant flavonoid, on epidermal ornithine decarboxylase and skin tumor promotion in mice. Cancer Res 50:499-502

Wei H, Bowen R, Cai Q, Barnes S, Wang Y (1995) Antioxidant and antipromotional effects of the soybean isoflavone genistein. Exp Biol Med 208(1):124-130

Wiegand H, Boesch-Saadatmandi C, Regos I, Treutter D, Wolffram S, Rimbach G (2009) Effects of quercetin and catechin on hepatic glutathione- $S$ transferase (GST), NAD(P)H quinone oxidoreductase 1 (NQO1), and antioxidant enzyme activity levels in rats. Nutr Cancer 61:717-722

Williams RJ, Spencer JPE, Rice-Evans C (2004) Flavonoids: antioxidants or signalling molecules? Free Radic Biol Med 36(7):838-849

Wilson RT, Wang J, Chinchilli V, Richie JP, Virtamo J, Moore LE, Albanes D (2009) Fish, vitamin D and flavonoids in relation to renal cell cancer among smokers. Am J Epidemiol 170(6):717-729

Wiseman H, Halliwell B (1996) Damage to DNA by reactive oxygen and nitrogen species: role in inflammatory disease and progression to cancer. Biochem J 313:17-29

Wiseman H, O'Reilly J, Lim P, Garnett AP, Huang WC, Sanders TAB (1998) Antioxidant properties of the isoflavone phytoestrogen functional ingredient in soy products. In: Sadler M, Saltmarsh M (eds) Functional foods, the consumer, the products and the evidence. Royal Society of Chemistry, Cambridge, pp 80-86

Wiseman H, O'Reilly JD, Adlercreutz H, Mallet AI, Bowey EA, Rowland IR, Sanders TAB (2000) Isoflavone phytoestrogens consumed in soy decrease F2-isoprostane concentrations and increase resistance of low-density lipoprotein to oxidation in humans. Am J Clin Nutr 72:395-400

Wiseman H, Casey K, Clarke DB, Barnes KA, Bowey E (2002) Isoflavone aglycone and glucoconjugate content of high- and low-soy UK foods used in nutritional studies. J Agric Food Chem 50:1404-1410

Wu B, Zhang Q, Shen W, Zhu J (2008) Antiproliferative and chemosensitizing effects of luteolin on human gastric cancer AGS cell line. Mol Cell Biochem 313:125-132

Xi J, Guo R (2008) Interactions of puerarin with micelles: pKa shifts and thermodynamics. J Solut Chem 37(1):107-118

Xiao CW (2008) Health effects of soy protein and isoflavones in humans. J Nutr 138:1244S-1249S 
Xiao ZP, Peng ZY, Peng MJ, Yan WB, Ouyang YZ, Zhu HL (2011) Flavonoids health benefits and their molecular mechanism. Med Chem 11(2):169-177

Xu WH, Yuan ZL (2009) Inhibition of experimental alkali-induced corneal neovascularization in rabbits by using genistein. Int $\mathbf{J}$ Ophthalmol (7)

Yang EB, Zhang K, Cheng LY, Mack P (1998) Butein, a specific protein tyrosine kinase inhibitor. Biochem Biophys Res Commun 245:435-438

Yang ZF, Poon RTP, Liu Y, Lau CK et al (2006) High doses of tyrosine kinase inhibitor PTK787 enhance the efficacy of ischemic hypoxia for the treatment of hepatocellular carcinoma: dual effects on cancer cell and angiogenesis. Mol Cancer Ther 5:2261-2270

Yang SF, Yang WE, Chang HR, Chu SC, Hsieh YS (2008) Luteolin induces apoptosis in oral squamous cancer cells. J Dent Res 87:401-406

Yoshizumi M, Tsuchiya K, Suzaki Y, Kirima K, Kyaw M, Moon JH, Terao J, Tamaki T (2002) Quercetin glucuronide prevents VSMC hypertrophy by angiotensin II via the inhibition of JNK and AP-1 signaling pathway. Biochem Biophys Res Commun 293:1458-1465

Young JF, Nielsen SE, Haraldsdottir J, Daneshvar B, Lauridsen ST, Knuthsen P, Crozier A, Sandström B, Dragsted LO (1999) Effect of fruit juice intake on urinary quercetin excretion and biomarkers of antioxidative status. Am J Clin Nutr 69:87-94

Zaman MS, Shahryari V, Deng G, Thamminana S, Saini S et al (2012) Up-regulation of microRNA-21 correlates with lower kidney cancer survival. PLoSONE 7(2):e31060

Zeleniuch-Jacquotte A, Adlercreutz H, Shore RE, Koenig KL, Kato I, Arslan AA, Toniolo P (2004) Circulating enterolactone and risk of breast cancer: a prospective study in New York. Br J Cancer 91(1):99-105

Zhang Q, Zhao XH, Wang ZJ (2008) Flavones and flavonols exert cytotoxic effects on a human oesophageal adenocarcinoma cell line (OE33) by causing G2/M arrest and inducing apoptosis. Food Chem Toxicol 46:2042-2053

Zhou JR, Mukherjee P, Gugger ET et al (1998) Inhibition of murine bladder tumorigenesis by soy isoflavones via alterations in the cell cycle, apoptosis, and angiogenesis. Cancer Res 58:52315238

Zi XL, Grasso AW, Kung HJ, Agarwal R (1998) A flavonoid antioxidant, silymarin, inhibits activation of erbB1 signaling and induces cyclin-dependent kinase inhibitors, G1 arrest and anticarcinogenic effects in human prostate carcinoma DU145 cells. Cancer Res 58:1920-1929 